\title{
Production of protein extracts from Swedish red, green, and brown seaweeds, Porphyra umbilicalis Kützing, Ulva lactuca Linnaeus, and Saccharina latissima (Linnaeus) J. V. Lamouroux using three different methods
}

\author{
Hanna Harrysson $^{1}$ (D) $\cdot$ Maria Hayes $^{2}$ - Friederike Eimer ${ }^{3} \cdot$ Nils-Gunnar Carlsson $^{1} \cdot$ Gunilla B. Toth $^{3} \cdot$ Ingrid Undeland $^{1}$
}

Received: 5 December 2017 / Revised and accepted: 16 April 2018 / Published online: 28 April 2018

(C) The Author(s) 2018

\begin{abstract}
The demand for vegetable proteins increases globally and seaweeds are considered novel and promising protein sources. However, the tough polysaccharide-rich cell walls and the abundance of polyphenols reduce the extractability and digestibility of seaweed proteins. Therefore, food grade, scalable, and environmentally friendly protein extraction techniques are required. To date, little work has been carried out on developing such methods taking into consideration the structural differences between seaweed species. In this work, three different protein extraction methods were applied to three Swedish seaweeds (Porphyra umbilicalis, Ulva lactuca, and Saccharina latissima). These methods included (I) a traditional method using sonication in water and subsequent ammonium sulfate-induced protein precipitation, (II) the $\mathrm{pH}$-shift protein extraction method using alkaline protein solubilization followed by isoelectric precipitation, and (III) the accelerated solvent extraction (ASE®) method where proteins are extracted after pre-removal of lipids and phlorotannins. The highest protein yields were achieved using the $\mathrm{pH}$-shift method applied to $P$. umbilicalis $(22.6 \pm 7.3 \%)$ and $S$. latissima $(25.1 \pm 0.9 \%)$. The traditional method resulted in the greatest protein yield when applied to U. lactuca $(19.6 \pm 0.8 \%)$. However, the protein concentration in the produced extracts was highest for all three species using the pH-shift method $(71.0 \pm 3.7 \%, 51.2 \pm 2.1 \%$, and $40.7 \pm 0.5 \%$ for P. umbilicalis, U. lactuca, and S. latissima, respectively). In addition, the $\mathrm{pH}$-shift method was found to concentrate the fatty acids in U. lactuca and S. latissima by 2.2 and 1.6 times, respectively. The $\mathrm{pH}$-shift method can therefore be considered a promising strategy for producing seaweed protein ingredients for use in food and feed.
\end{abstract}

Keywords Seaweed · Protein extraction - Ammonium sulfate precipitation $\cdot \mathrm{pH}$ shift $\cdot$ Accelerated solvent extraction (ASE®) · Amino acids

\section{Introduction}

By the year 2050, the global human population is estimated to reach 9.7 billion (United Nations 2017), and the food

Hanna Harrysson

harryssh@chalmers.se

1 Department of Biology and Biological Engineering-Food and Nutrition Science, Chalmers University of Technology, SE-412 96 Gothenburg, Sweden

2 Food BioSciences Department, Teagasc Food Research Centre, Ashtown, Dublin 15, Ireland

3 Department of Marine Sciences - Tjärnö, University of Gothenburg, Strömstad, Sweden requirements are estimated to be $60 \%$ higher (Alexandratos and Bruinsma 2012) than those today. In a review by Aiking (2014), it is argued that a decrease in animal-based proteins is a prominent option to reach a more sustainable food supply chain in the future. Therefore, there is a requirement for new sources of vegetable proteins. Certain seaweeds are rich in proteins, e.g., some red seaweed species are reported to contain up to $47 \%$ protein (dry weight, dw, basis) (FujiwaraArasaki et al. 1984; Černá 2011). The productivity of seaweed beds can also be several times higher than that in terrestrial systems (Leigh et al. 1987), making seaweeds a promising source for vegetable proteins.

In addition to the high protein content, seaweeds contain other interesting compounds from a food point of view. Even if the fat content of seaweeds is low, it consists of high levels of long-chain n3 polyunsaturated fatty acids (LC n3 PUFA) 
and especially red seaweed species can contain high levels of eicosapentaenoic acid (EPA) (Fleurence et al. 1994; Matanjun et al. 2009; Cian et al. 2014; Maehre et al. 2014; Rodrigues et al. 2015). For example, Fleurence et al. (1994) reported that EPA constitutes $48 \%$ of the total fatty acid content in Porphyra umbilicalis. Also, docosahexaenoic acid (DHA) has been reported in low amounts in some red (Fleurence et al. 1994), green (Ortiz et al. 2006) (i.e., Ulva lactuca), and brown (Ortiz et al. 2006; Matanjun et al. 2009; Veide Vilg et al. 2015) seaweed species. However, for the brown seaweed Saccharina latissima, the DHA levels vary with both location and season of harvest but can make up $8.5 \%$ of the total fatty acid content (Veide Vilg et al. 2015). Seaweeds are also high in minerals, with reported ash levels for most species varying between 20 and 40\% dw (Wong and Cheung 2000; Rupérez 2002; Aguilera-Morales et al. 2005; Ortiz et al. 2006; Matanjun et al. 2009; Peña-Rodríguez et al. 2011; Yaich et al. 2011; Maehre et al. 2014; Rodrigues et al. 2015; Veide Vilg et al. 2015); however, both lower (Ortiz et al. 2006; Cian et al. 2014; Veide Vilg et al. 2015) and higher (Matanjun et al. 2009; Peña-Rodríguez et al. 2011; Maehre et al. 2014) values have been reported. The high abundance of minerals could be interesting from a food perspective for use as salt replacers and/or as a source of important minerals (Rupérez 2002).

Seaweeds have a very tough polysaccharide-rich cell wall and the cell wall mucilage reduces the extractability of proteins (Fleurence et al. 1995). The extractability of proteins is affected both by the high viscosity that the polysaccharides exert in a water solution and by the ionic interactions between the cell wall and the proteins (Joubert and Fleurence 2008). Also, the abundance of phenols, such as phlorotannins in brown seaweeds (Hurd et al. 2014), can decrease the extractability further (Jordan and Vilter 1991) as well as reducing the digestibility of the proteins (Wong and Cheung 2001; Ozdal et al. 2013) by binding the proteins either covalently or by non-covalent forces (Jordan and Vilter 1991; Stern et al. 1996; Ozdal et al. 2013).

To separate proteins from polysaccharides and phenolic compounds and, at the same time, improve the protein content and sensory properties, food grade, scalable, and environmentally friendly techniques for extracting seaweed proteins are desirable. Most reported techniques for extraction of proteins from seaweeds utilize water only (i.e., Galland-Irmouli et al. (1999) and Garcia-Vaquero et al. (2017)) or a water extraction followed by a second alkaline extraction in the presence of mercaptoethanol (i.e., Wong and Cheung (2001), Kandasamy et al. (2012), and Suresh Kumar et al. (2014)) followed finally by precipitation with ammonium sulfate. The $\mathrm{pH}$-shift process (Fig. 1), with alkaline protein solubilization followed by isoelectric precipitation, commonly used for extraction of protein from fish muscle (Undeland et al. 2002; Marmon and Undeland 2010), was recently applied to S. latissima by
Fig. 1 Schematic overview of the final $\mathrm{pH}$-shift method, used to compare with the traditional method and ASE method. "Pellet 2 " indicates the final protein extract

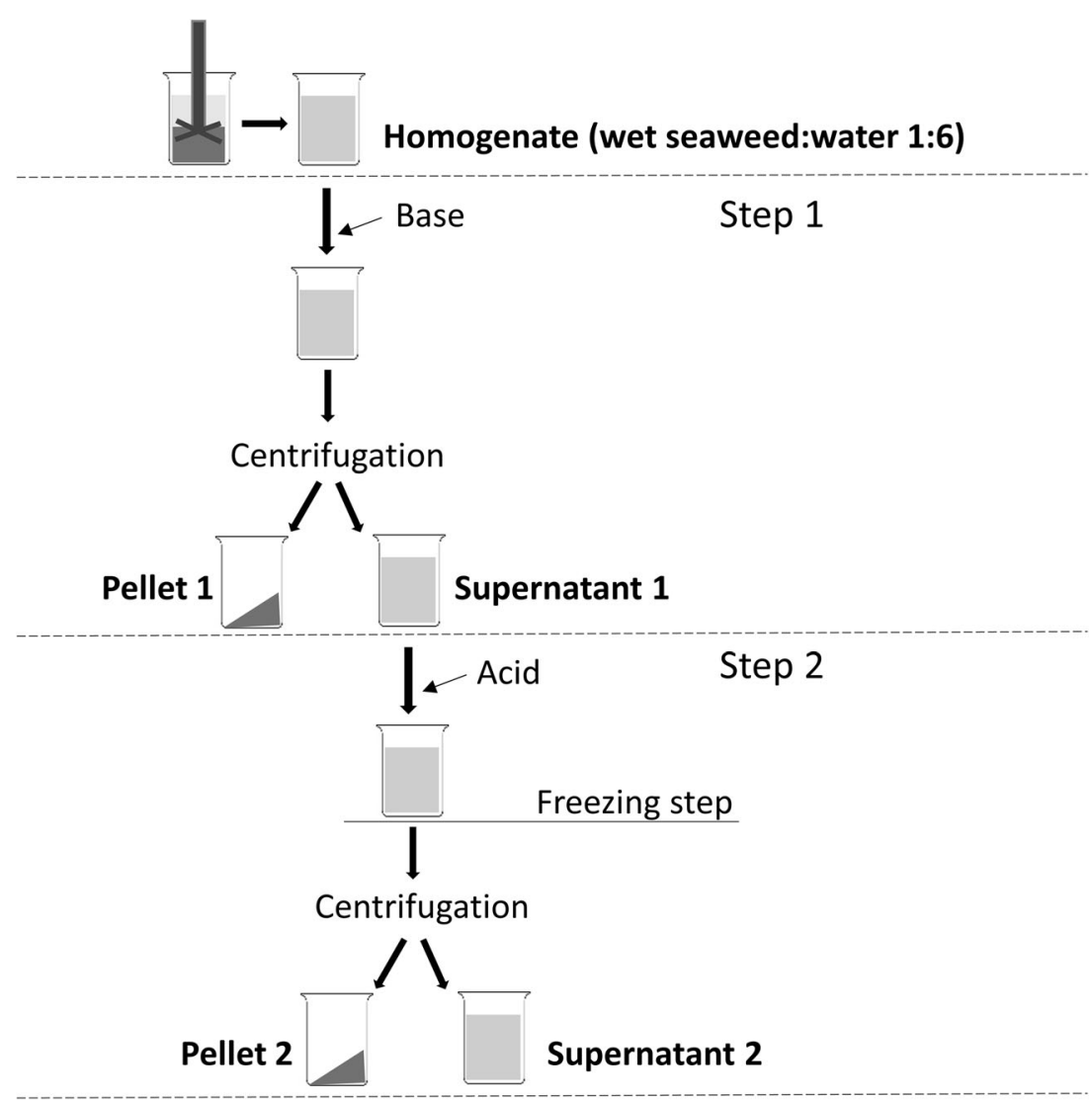


Veide Vilg and Undeland (2017) with the addition of an osmotic shock step. In this study (Veide Vilg and Undeland 2017), the total protein yield was $16 \%$. By using accelerated solvent extraction (ASE®), also known as pressurized liquid extraction (PLE), which combines temperature and pressure to generate extracts using food grade solvents, proteins are extracted after pre-removal of lipids and phlorotannins. A review by Herrero et al. (2015) discusses how ASE® was previously used for extraction of different bioactive compounds from seaweeds and microalgae.

Since the composition and structure of different seaweeds vary largely (Hurd et al. 2014), different species are expected to respond differently to different protein extraction procedures. A careful mapping of the best process-species combinations would be of great help when building future seaweed bio-refineries. To our knowledge, no study carried out to date compares different protein extraction methods on red, green, and brown seaweeds and therefore the aims of this work were to (I) generate protein extracts from P. umbilicalis, U. lactuca, and $S$. latissima using three different extraction methods including a traditional method using ammonium sulfate salting out, the pH-shift method, and the ASE® method; (II) determine the yield of protein obtained; and (III) determine the quality of the obtained protein extracts in terms of their crude composition and their amino acid and fatty acid composition.

\section{Materials and method}

\section{Chemicals}

Diethyl ether, Folin-Ciocalteu phenol, petroleum ether, sodium carbonate, sodium chloride, sodium dodecyl sulfate, and sodium tartrate were from Sigma-Aldrich (Sweden). Sodium hydroxide and toluene were from Scharlau (Spain). Acetic acid was from Fischer Scientific (Sweden), acetyl chloride and copper sulfate were from Fluka (Switzerland), hydrochloric acid was from Acros (Sweden), and methanol was from Honey well Riedel-de Haen (Sweden). Acetone, ammonium sulfate, hexane, and methanol were from Sigma-Aldrich (Ireland).

\section{Seaweed raw material}

Porphyra umbilicalis tufts were collected at Inre Vattenholmen $\left(58^{\circ} 52.622 \mathrm{~N} ; 11^{\circ} 6.876 \mathrm{E}\right)$ on 2 April 2016 and rinsed several times in natural seawater to remove grazers and loose epiphytes. Tufts were then placed into cultivation tanks (see below).

Cultivated gametophytes from U. lactuca were fragmented and subjected to temperature shock to induce the production of reproductive tissue. After 2 days, released gametes germinated and attached to sterile petri dishes. After 2 months in petri dishes, juvenile $U$. lactuca were placed into cultivation tanks (see below).
Adult S. latissima sori were dried and subjected to cold temperature shock overnight. In the morning, sori were submerged in seawater and spore release occurred shortly after. After 2 months in petri dishes, juvenile $S$. latissima were placed into cultivation tanks.

All seaweeds were cultivated at the Sven Loven Center for Marine Infrastructure at Tjärnö, Sweden (58 $52^{\circ} 33.2724^{\prime \prime} \mathrm{N}$, $\left.11^{\circ} 8^{\prime} 47.202^{\prime \prime} \mathrm{E}\right)$, in 80 -L cultivation tanks at $12^{\circ} \mathrm{C}$ and with a neutral light-cycle (12-h daylights, 12-h darkness) at light intensity of $50 \mu \mathrm{mol}$ photons $\mathrm{m}^{-2} \mathrm{~s}^{-1}$. Seaweeds received continuous filtered seawater. The lowest filter size used was $1 \mu \mathrm{m}$ and all seawater was treated with UV prior to entering the cultivation tanks. No additional medium was added.

\section{Extraction of proteins}

Proteins were extracted from freeze-dried and milled $P$. umbilicalis, U. lactuca, and S. latissima biomass using three different methods. The total protein yield for respective species/method combinations was calculated according to the following equation: $100 \times(($ protein content in extract $\times$ amount extract achieved)/(protein content in crude seaweed $\times$ amount seaweed used)). Thus, the total yield is the protein obtained in the different processes divided by the amount ingoing protein. The total protein content was analyzed with the Lowry method (Lowry et al. 1951) as further modified by Markwell et al. (1978) and as total amount amino acids. Compositional analysis was performed in triplicate on extracts from each process type.

\section{Traditional protein extraction using sonication in water and ammonium sulfate precipitation of protein}

Seaweed proteins were extracted using the method previously described by Galland-Irmouli et al. (1999). Briefly, $10 \mathrm{~g}$ of freeze-dried and milled seaweed was independently suspended in $1 \mathrm{~L}$ of ultrapure Milli-Q water. Following ultra-sonication for $1 \mathrm{~h}$, the seaweed solution was left to stir overnight on a magnetic stirrer plate at $4{ }^{\circ} \mathrm{C}$. The solution was then centrifuged at $10000 \times \mathrm{g}$ for $1 \mathrm{~h}$ and the supernatant decanted. The pellet fraction was suspended in $200 \mathrm{~mL}$ of Milli-Q water and subjected to a second extraction procedure as described above. Both supernatants were pooled together for each seaweed species and subsequently brought to $80 \%$ $(w / v)$ ammonium sulfate saturation, stirred for $1 \mathrm{~h}$ at $4{ }^{\circ} \mathrm{C}$, and centrifuged at $20,000 \times g$ for $1 \mathrm{~h}$ to precipitate the protein fraction. The precipitates were subsequently dialyzed using 3.5kDa MWCO dialysis tubing (Fischer Scientific, USA) against Milli-Q water at $4{ }^{\circ} \mathrm{C}$ overnight. The precipitates were subsequently freeze-dried and stored at $-80{ }^{\circ} \mathrm{C}$ until further use. The traditional protein extraction method was performed in duplicate for all species and one of the produced extracts was used for compositional analyses. 


\section{pH-shift protein extraction}

Proteins were extracted from seaweeds using the $\mathrm{pH}$-shift method according to Veide Vilg and Undeland (2017). However, the method first had to be adapted for U. lactuca and $P$. umbilicalis by determining the solubility maxima and precipitation maxima of the proteins. Those experiments were performed in duplicate.

Adaption of the pH-shift process to Porphyra umbilicalis and Ulva lactuca According to Veide Vilg and Undeland (2017), biomass was homogenized in distillated water in a 1:4 $(w / v)$ ratio based on the wet weight of each seaweed species, and stirred for $1 \mathrm{~h}$ at $8{ }^{\circ} \mathrm{C}$. The protein content in the homogenate was analyzed using the method of Lowry et al. (1951) (see below). To determine the maximum solubility, the $\mathrm{pH}$ of the seaweed water mix was stepwise adjusted from its native $\mathrm{pH}$ (6.1 \pm 0.1 and $4.8 \pm 0.1$ for P. umbilicalis and U. lactuca, respectively) either upwards (with $1 \mathrm{M} \mathrm{NaOH}$ ) to a maximum value of $\mathrm{pH} 13$, or downwards (with $1 \mathrm{M} \mathrm{HCl}$ ) to a minimum value of $\mathrm{pH} 2$. At each $\mathrm{pH}$ examined, sub-samples were withdrawn, centrifuged at $8000 \times \mathrm{g}$ for $10 \mathrm{~min}$ and the protein content analyzed in supernatant 1 (Fig. 1) according to Lowry et al. (1951). The solubility at each $\mathrm{pH}$ step was calculated according to Eq. 1.

Solubility $=100 \times\left(\frac{\text { conc supernatant } 1}{\text { conc homogenate }}\right)$

The precipitation maxima were then determined by adjusting the $\mathrm{pH}$ of the supernatant recovered at $\mathrm{pH} 12$ (which gave the highest solubility) to $\mathrm{pH}$ values between $\mathrm{pH} 2$ and 7 (for P. umbilicalis) and between $\mathrm{pH} 2$ and 6 (for U. lactuca), followed by a second centrifugation at $8000 \times g$ for $10 \mathrm{~min}$. Subsamples were withdrawn from supernatant 1 at each $\mathrm{pH}$ both before centrifugation and after the second centrifugation step, i.e., from supernatant 2 . The protein content of these samples was analyzed according to Lowry et al. (1951) (see below). The precipitation at each $\mathrm{pH}$ step was calculated according to Eq. 2.

Precipiation $=100 \times\left(1-\left(\frac{\text { conc supernatant } 2}{\text { conc supernatant } 1}\right)\right)$

To increase the protein yield further during precipitation, a freezing step was applied to supernatant 1 after the $\mathrm{pH}$ was decreased. The effect of this step was also examined for $S$. latissima. Further, to increase the overall yield, extraction with a larger volume of water $(1: 6(w / v)$, based on the wet weight of each seaweed species) was investigated.

Production of protein extracts with the adapted $\mathrm{pH}$-shift methods By using the adapted $\mathrm{pH}$ values for solubilization and precipitation for P. umbilicalis and U. lactuca and the ones determined by Veide Vilg and Undeland (2017) for $S$. latissima, protein extracts were produced for the three seaweed species by homogenizing each dry-milled seaweed independently in distilled water in a 1:6 (w/v) ratio, based on the original wet weight of each seaweed species. Homogenization was done with an Ultra Turrax T18 basic (IKA, Germany) for 2 min at a speed of 4 (18,000 rpm) followed by milling with beads using a Retsch MM 400 at speed 1/30 s for 2 min. The homogenized sample was stirred for $1 \mathrm{~h}$ at $8^{\circ} \mathrm{C}$ and thereafter the $\mathrm{pH}$ was adjusted to 12 (which gave the highest protein solubility) while the sample was kept on ice. Following centrifugation at $8000 \times \mathrm{g}$ for $10 \mathrm{~min}$, the supernatant containing the solubilized proteins was decanted and the $\mathrm{pH}$ was adjusted to $\mathrm{pH} 2$ and the supernatant was frozen overnight at $-20^{\circ} \mathrm{C}$. After thawing and a second centrifugation at $8000 \times \mathrm{g}$ for $10 \mathrm{~min}$, the pellet was collected, freeze dried, and stored at $-80{ }^{\circ} \mathrm{C}$ until further analysis. The $\mathrm{pH}$-shift protein extraction method was performed in duplicate for all species with the produced extracts being pooled for each species before compositional analysis.

\section{Accelerated solvent extraction}

ASE® extraction was carried out to extract lipids, phlorotannins, and carbohydrates prior to extraction of proteins as was previously described by Lopes et al., (2012). Seaweed lipids were removed using hexane. De-fatted seaweed material was left to dry overnight in a fume hood at room temperature (RT). This material was subsequently used as the substrate for carbohydrate/phlorotannin extraction using ASE®. ASE® was performed using the Dionex PLE System (ASE 200, Dionex, Germany) according to the previously published method (Lopes et al., 2012) with some modifications. The phlorotannin/carbohydrate fractions were generated according to the method of Lopes et al. (2012) with minor modifications as follows: $1 \mathrm{~g}$ of each freeze-dried and de-fatted powdered seaweed was mixed with $4 \mathrm{~g}$ of silica (Merck grade, 60 Å, Sigma-Aldrich, USA). Silica was used as an inert dispersant and the sample plus silica mixture was then packed into $22-\mathrm{mL}$ extraction cells. The automated extraction method used $70 \%$ food grade acetone in water and a pressure and temperature of $1000 \mathrm{psi}$ and $0{ }^{\circ} \mathrm{C}$, respectively. The extraction time consisted of 1 cycle of $7 \mathrm{~min}$. The recovered fractions were subsequently frozen at $-80^{\circ} \mathrm{C}$ and evaporated to dryness at $30^{\circ} \mathrm{C}$ under pressure before being freezedried using an industrial scale FD80 model freeze-drier (Cuddon Engineering, New Zealand) for $24 \mathrm{~h}$ to eliminate residual water. The seaweed/silica residue was used for protein extraction using ASE®. ASE® protein extraction was carried out by mixing $1 \mathrm{~g}$ of air-dried seaweed/silica residue with $4 \mathrm{~g}$ of silica which was packed into $22-\mathrm{mL}$ extraction cells. The automated extraction method used $50 \%$ methanol in water and a pressure and temperature of $1500 \mathrm{psi}$ and $37^{\circ} \mathrm{C}$, 
respectively. The extraction time consisted of 2 cycles of $5 \mathrm{~min}$. The recovered fractions were dried using rotary evaporation to remove methanol, frozen at $-80{ }^{\circ} \mathrm{C}$, and freezedried for $24 \mathrm{~h}$ to eliminate water as previously described. Protein fractions were then stored at $-80{ }^{\circ} \mathrm{C}$ until compositional analysis was performed. The ASE protein extraction technique was performed as singlets for each seaweed species.

\section{Total proteins}

The total protein content in the seaweeds and seaweed protein extracts was determined according to the method of Lowry et al. (1951) modified by Markwell et al. (1978). Twenty milligram of each dried extract or dried seaweed was vortexed independently in $1 \mathrm{~mL} 0.1 \mathrm{M} \mathrm{NaOH}$ and diluted further between 10 and 100 times with $0.1 \mathrm{M} \mathrm{NaOH}$. For homogenates and supernatants, $0.1 \mathrm{~mL}$ was mixed with $0.9 \mathrm{~mL} \mathrm{NaOH}$ and vortexed before eventual further dilution (up to 20 times). To a 1 -mL sample, $3 \mathrm{~mL}$ of freshly made reagent $\left(1\right.$ part $4 \% \mathrm{CuSO}_{4}$ $\cdot 5 \mathrm{H}_{2} \mathrm{O}$ into 100 parts of a mixture of $2.0 \% \mathrm{Na}_{2} \mathrm{CO}_{3}, 0.40 \%$ $\mathrm{NaOH}, 0.16 \%$ Na-tartrate, and $1 \%$ SDS) was added before incubation for $30 \mathrm{~min}$ at RT. Thereafter, $0.3 \mathrm{~mL}$ freshly made phenol reagent (1 part Folin-Ciocalteu phenol reagent into 1 part Milli-Q water) was added and the samples were incubated for $45 \mathrm{~min}$ in darkness at RT. A Cary60 UV-VIS spectrophotometer (Agilent Technologies, USA) was used for absorbance measurements at $750 \mathrm{~nm}$. A standard curve made from bovine serum albumin (BSA) was used for quantification.

\section{Amino acids}

Amino acid analysis was carried out using a modified version of the method of Özcan and Șenyuva (2006). To $100 \mathrm{mg}$ of dry protein extract or dry seaweed, $10 \mathrm{~mL}$ of $6 \mathrm{M} \mathrm{HCl}$ was added and thereafter hydrolysis was carried out at $110^{\circ} \mathrm{C}$ for $24 \mathrm{~h}$. One milliliter of each of the hydrolyzed samples was dried by flushing with air and subsequently re-dissolved in $1 \mathrm{~mL} 0.2 \mathrm{M} \mathrm{HAc}$. Five microliter was injected onto the LCMS system consisting of an Agilent 1260 HPLC with a binary pump, an auto sampler, and a column oven with a Phenomenex column (C18 (2) $250 \mu \mathrm{m} \times 4.6 \mu \mathrm{m} \times 3 \mu \mathrm{m})$, coupled to an Agilent 6120 quadrupole in the SIM positive mode (Agilent Technologies, Germany). As mobile phase A, $3 \% \mathrm{MeOH}, 0.2 \%$ formic acid, and $0.01 \% \mathrm{HAc}$ were used and as mobile phase $\mathrm{B}, 50 / 50 \mathrm{MeOH} / \mathrm{H}_{2} 0$ with $0.2 \%$ formic acid and $0.01 \% \mathrm{HAc}$ were used. The initial gradient, held for the first 8 min, was $94 \%$ of A and $6 \%$ of B. The gradient was then gradually changed until it reached $80 \%$ of $\mathrm{A}$ and $20 \%$ of $\mathrm{B}$ after $20 \mathrm{~min}$. This gradient was held until $27 \mathrm{~min}$, changed gradually until it reached $94 \% \mathrm{~A}$ and $6 \% \mathrm{~B}$ after $28 \mathrm{~min}$, and thereafter held the rest of the run (total $40 \mathrm{~min}$ ). As standard curve, a mix consisted of 24 amino acids diluted in $0.2 \mathrm{~m} \mathrm{HAc}$ in the range 1-20 ppm was used. Due to the use of acidic hydrolysis, tryptophan could not be analyzed. Results are expressed as percent total amino acids in the seaweeds and extracts on a dry weight basis, and as percent of each amino acid out of the total amount of amino acids.

\section{Fatty acids}

Fatty acids were directly trans-esterified according to Cavonius et al. (2014). An internal standard (C17:0) in toluene was added to $25 \mathrm{mg}$ of freeze-dried extract or dried seaweed. One milliliter of toluene and $1 \mathrm{~mL}$ of $10 \% \mathrm{HCl}$ in methanol were added before the sample was incubated at $70{ }^{\circ} \mathrm{C}$ for $2 \mathrm{~h}$. The reaction was stopped by adding $0.2 \mathrm{~mL}$ Milli-Q water. Five milliliter of ether solvent (petroleum ether $80 \% v / v$ and diethyl ether $20 \% \mathrm{v} / \mathrm{v}$ ) was added and the sample was vortexed. After centrifugation $(2500 \times \mathrm{g}$ for $6 \mathrm{~min})$, the organic phase was evaporated under nitrogen and re-dissolved in isooctane and injected onto an Agilent 7890 A GC system equipped with a VF-WAX column $(30 \mathrm{~cm} \times 0.250 \mathrm{~mm} \times$ $0.25 \mu \mathrm{m}$ ) (Netherlands) and interfaced with an Agilent 5975 $\mathrm{C}$ triple-axis MS detector (USA) in electron impact mode. The injection volume was $1 \mu \mathrm{L}$ with a 15:1 split at an inlet temperature of $275^{\circ} \mathrm{C}$. The carrier gas was helium, with a fixed flow of $1 \mathrm{~mL} \mathrm{~min}^{-1}$. The temperature started at $100{ }^{\circ} \mathrm{C}$ and increased by $4{ }^{\circ} \mathrm{C} \min ^{-1}$ to $205{ }^{\circ} \mathrm{C}$ and was thereafter increased further with $1{ }^{\circ} \mathrm{C} \min ^{-1}$ to $230{ }^{\circ} \mathrm{C}$, and kept for the final $5 \mathrm{~min}$. Fatty acids were quantified against the internal standard. Identification of fatty acids was done by using GLC Reference Standard 463 from Nu-Chek Prep, Inc., except for C16:1 n9 C16:2 n9, C16:4 n3, C18:4 n3, and C20:4 n3 which was determined using the MS-library. Results are expressed as percent total fatty acids in the seaweeds and extracts on a dry weight basis, and as percent of each fatty acid out of the total amount of fatty acids.

\section{Ash}

The ash content was determined by combusting $50 \mathrm{mg}$ of either dry protein extract or dry seaweed at $550{ }^{\circ} \mathrm{C}$ for $3 \mathrm{~h}$ in a furnace. The samples were left in the oven to cool to $300^{\circ} \mathrm{C}$, further cooled in a desiccator and thereafter the weight was recorded. Results are expressed as percent ash on a dry weight basis.

\section{lonic strength}

The ionic strength during the $\mathrm{pH}$-shift process was determined by using a CDM210 conductivity meter (MeterLab, France). Sodium chloride $(\mathrm{NaCl})$ was used as a standard and the results are expressed as percent $\mathrm{NaCl}$ equivalents in homogenates. 


\section{Statistical analyses}

Data on protein yield for the extracts obtained with the traditional and $\mathrm{pH}$ shift extraction methods from P. umbilicalis, $U$. lactuca, and S. latissima, measured as total amino acids and with the Lowry method, were statistically analyzed using a three-way analysis of variance (ANOVA) with extraction method (2 levels), species (3 levels), and protein analysis (2 levels) as fixed, orthogonal factors (Table 1). Data on protein yield from the ASE® extraction method were not included in the statistical analysis because only one extract was obtained from each seaweed species. However, data is included in Fig. 3 for visual comparison.

Data on the total amino acid, total fatty acid, and ash content $(\% \mathrm{dw})$ in the crude seaweed material, as well as in the protein extracts obtained with the traditional, $\mathrm{pH}$-shift, and ASE® extraction methods from P. umbilicalis, U. lactuca, and $S$. latissima were statistically analyzed using a two-way ANOVA with analyzed material (4 levels) and species (3 levels) as fixed, orthogonal factors. The residual degrees of freedom (df) in the ANOVAs were adjusted to account for missing replicates being replaced with the mean values (see Table 2 and Fig. 4) (Underwood 1997). Means were compared using the Student-Newman-Keuls (SNK) procedure (Underwood 1997).

\section{Results}

\section{Adaptation of the pH-shift technique to Ulva lactuca and Porphyra umbilicalis}

The solubility of proteins increased for $U$. lactuca with increased $\mathrm{pH}$ within the studied range (pH 2-13) (Fig. 2). However, to reach a $\mathrm{pH}$ over 12 required the use of a large amount of base (approximately 50 times more base was needed between $\mathrm{pH} 12$ and 13 than between $\mathrm{pH} 6$ and 7) and therefore $\mathrm{pH} 12$ was selected as the most appropriate $\mathrm{pH}$ for solubilization of $U$. lactuca proteins. The solubility here was $62.1 \pm 5.1 \%$. The solubility of $P$. umbilicalis proteins also increased with increased $\mathrm{pH}$ and reached a maximum of $54.2 \pm$
$4.9 \%$ at $\mathrm{pH} 12$ (Fig. 2). Ionic strength in the U. lactuca homogenate upon solubilization at $\mathrm{pH} 12$ was $74 \mathrm{mM} \mathrm{NaCl}$ equivalents. For $P$. umbilicalis, it was $83 \mathrm{mM} \mathrm{NaCl}$ equivalents.

The highest protein precipitation for both P. umbilicalis and U. lactuca (Fig. 2), after previous solubilization at $\mathrm{pH} 12$ and centrifugation at $8000 \times \mathrm{g}$ for $10 \mathrm{~min}$, was achieved at $\mathrm{pH} 2$; $33.3 \pm 0.9 \%$ and $22.7 \pm 8.01 \%$, respectively. Applying a freezing step to supernatant 1 after adjustment to $\mathrm{pH} 2$ increased the precipitation of $P$. umbilicalis and $U$. lactuca proteins further, by 8 , respectively, 4 percentage points. For $S$. latissima, it increased the precipitation by 14 percentage points.

The calculated total protein yield over the whole $\mathrm{pH}$-shift process for P. umbilicalis and U. lactuca was $13.7 \pm 0.2 \%$ and $6.6 \pm 2.5 \%$, respectively, based on protein measurements in the two supernatants. However, the yield in the precipitation step of $U$. lactuca varied a lot, resulting in variances also in total protein yield. Extracting proteins from P. umbilicalis using a larger volume of water (1:6 w/v as opposed to $1: 4 w / v)$ increased the total protein yield by 8 percentage points (from 13.7 to $21.7 \%$ ) and adding the freezing-thawing step during precipitation enhanced the yield further by 4 percentage points (from 21.7 to $26.0 \%$ ). For $U$. lactuca, the general variation in protein yield overshadowed the effect achieved using the larger extraction volume; however, adding of the freeze-thawing step gave a slightly higher yield ( 2 percentage points increase, from 6.4 to $8.1 \%$ ). When using the previously recommended $\mathrm{pH}$ values for solubilization $(\mathrm{pH} 12)$ and precipitation $(\mathrm{pH} 2)$ for S. latissima (Veide Vilg and Undeland 2017) and combining this with a larger extraction volume (1:6 as opposed to 1:4) and a freezing-enhanced precipitation step, the total calculated protein yield achieved was 33\% based on protein measurements in the supernatants.

\section{Protein yield with the three protein extraction procedures}

When data for the total protein yield for extracts from different seaweed species obtained using different extraction methods were statistically analyzed, we found a significant interaction between the factors species and extraction method (Table 1).
Table 1 Analysis of the variance in the total protein yield $(\%)$ from Porphyra umbilicalis, Ulva lactuca, and Saccharina latissima (species) obtained with the traditional and $\mathrm{pH}$-shift methods (extraction method). Data on mean values and SEM are presented in Fig. 3

\begin{tabular}{lcccc}
\hline Source & df & Mean square & $F$ value & $P$ value \\
\hline Analysis & 1 & 76.43 & 4.95 & 0.0461 \\
Species & 2 & 10.27 & 0.66 & 0.5323 \\
Extraction method & 1 & 489.74 & 31.69 & 0.0001 \\
Analysis $\times$ species & 2 & 8.47 & 0.55 & 0.592 \\
Species $\times$ extraction method & 2 & 476.77 & 30.85 & 0.0001 \\
Analysis $\times$ extraction method & 1 & 0.73 & 0.05 & 0.8318 \\
Analysis $\times$ species $\times$ extraction method & 2 & 16.48 & 1.07 & 0.3747 \\
Residual & 12 & 15.45 & & \\
\hline
\end{tabular}


Table 2 Analysis of the variance in the content (\% dw) of (A) total amino acids, (B) total fatty acids, and (C) ash of Porphyra umbilicalis, Ulva lactuca, and Saccharina latissima (species) measured in crude seaweed material, as well as in extracts obtained with the traditional, $\mathrm{pH}$ - shift, and the ASE® methods (analyzed material). The residual degrees of freedom (df) were adjusted to account for missing data. Data on mean values and SEM are presented in Fig. 4

\begin{tabular}{|c|c|c|c|c|c|c|c|c|c|c|c|c|}
\hline \multirow[b]{2}{*}{ Source of variation } & \multicolumn{4}{|c|}{ A. Amino acids (\% dw) } & \multicolumn{4}{|c|}{ B. Fatty acids (\% dw) } & \multicolumn{4}{|c|}{ C. Ash (\% dw) } \\
\hline & df & MS & $F$ & $p$ & df & MS & $F$ & $p$ & df & MS & $F$ & $p$ \\
\hline Species & 2 & 1210.31 & 616.49 & 0.0001 & 2 & 3.07 & 99.65 & 0.0001 & 2 & 692.26 & 351.51 & 0.0001 \\
\hline Analyzed material & 3 & 3793.40 & 1932.22 & 0.0001 & 3 & 15.52 & 503.42 & 0.0001 & 3 & 5002.76 & 2540.28 & 0.0001 \\
\hline Species $\times$ extracted material & 6 & 58.52 & 29.81 & 0.0001 & 6 & 1.47 & 47.59 & 0.0001 & 6 & 142.29 & 72.25 & 0.0001 \\
\hline Residual & 20 & 1.96 & & & 20 & 0.03 & & & 16 & 1.97 & & \\
\hline
\end{tabular}

The total protein yield was significantly (SNK, $p<0.05$ ) higher for the extracts obtained with the $\mathrm{pH}$-shift method for P. umbilicalis and S. latissima, compared to that of the extracts obtained with the traditional method (Fig. 3a, b). For the extracts from U. lactuca, a non-significant (SNK, $p>0.05$ ) trend towards a higher protein yield in the extract obtained with the traditional method, compared to the $\mathrm{pH}-$ shift method, was found (Fig. 3a, b). The ASE® method was only used once to obtain extracts from the three seaweed species, and therefore the data could not be included in the statistical analysis. However, the total protein yield for these extracts was lower compared to the mean values for the extracts obtained with the traditional and the $\mathrm{pH}$ shift methods (Fig. 3a, b).

We also detected a significant difference in the total protein yield estimated with the different analysis methods (Table 1). The Lowry method (Fig. 3a) consistently resulted in significantly $(\mathrm{SNK}, p<0.05)$ higher total protein yield estimates compared to when the protein yield was estimated based on analysis of total amino acids (Fig. 3b). On average, the Lowry method resulted in $34.3 \%$ higher estimates of total protein yield compared to the analysis of total amino acids. These results indicate the importance of the chosen protein measurement method selected for protein analysis as highlighted recently by Maehre et al. (2018).

\section{Composition of seaweed biomass and protein extracts}

When data from the different compositional analyses in crude seaweed material and in extracts obtained with different extraction methods were statistically analyzed, we found highly significant interactions between the main factors - species and extracted material (Table 2). There were statistically significant differences (SNK, $p<0.05$ ) in the total amino acid and fatty acid content, as well as ash content, between all the extracted materials, but the size of the effect differed between different seaweed species (Fig. 4). The pH-shift method concentrated the proteins most efficiently, and the concentration factor ranking order for the different seaweeds was $S$. latissima (4.0 times) $>U$. lactuca (2.6 times) $>P$. umbilicalis (2.2 times). The total fatty acid content in the P. umbilicalis $\mathrm{pH}$-shift extract was slightly reduced compared to that in the crude seaweed; however, for both U. lactuca and S. latissima pH-shift extracts, it was concentrated, 2.2 and 1.6 times, respectively, compared to their crude seaweeds. The traditional method when applied to the seaweeds resulted in the generation of extracts with lower protein concentrations than in their respective crude seaweeds. The same was also true for the total fatty acids and ash contents achieved in the traditional extracts (see Fig. 4). Also with the ASE® method, the protein content and fatty acid content were
Fig. 2 a Protein solubility of Porphyra umbilicalis and Ulva lactuca in four volumes of water (based on the wet weight) at different $\mathrm{pHs}$ in the $\mathrm{pH}$-shift method. b Protein precipitation for Porphyra umbilicalis and Ulva lactuca at different $\mathrm{pHs}$ when using the $\mathrm{pH}$-shift method with initial solubilization at $\mathrm{pH} 12$ followed by centrifugation at $8000 \times g$ (note that the $y$-axes in panels $\mathbf{a}$ and $\mathbf{b}$ differ)
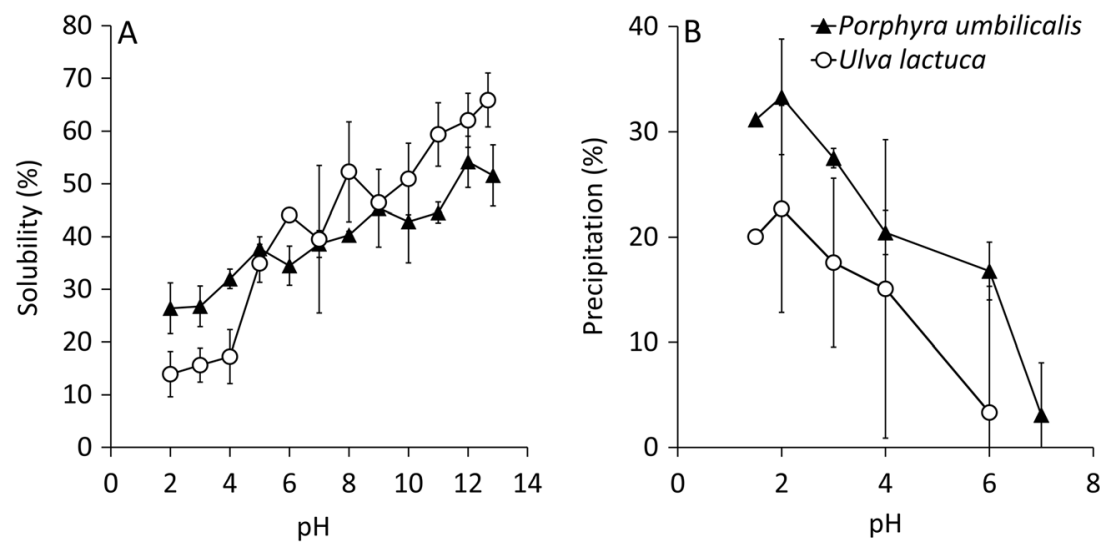


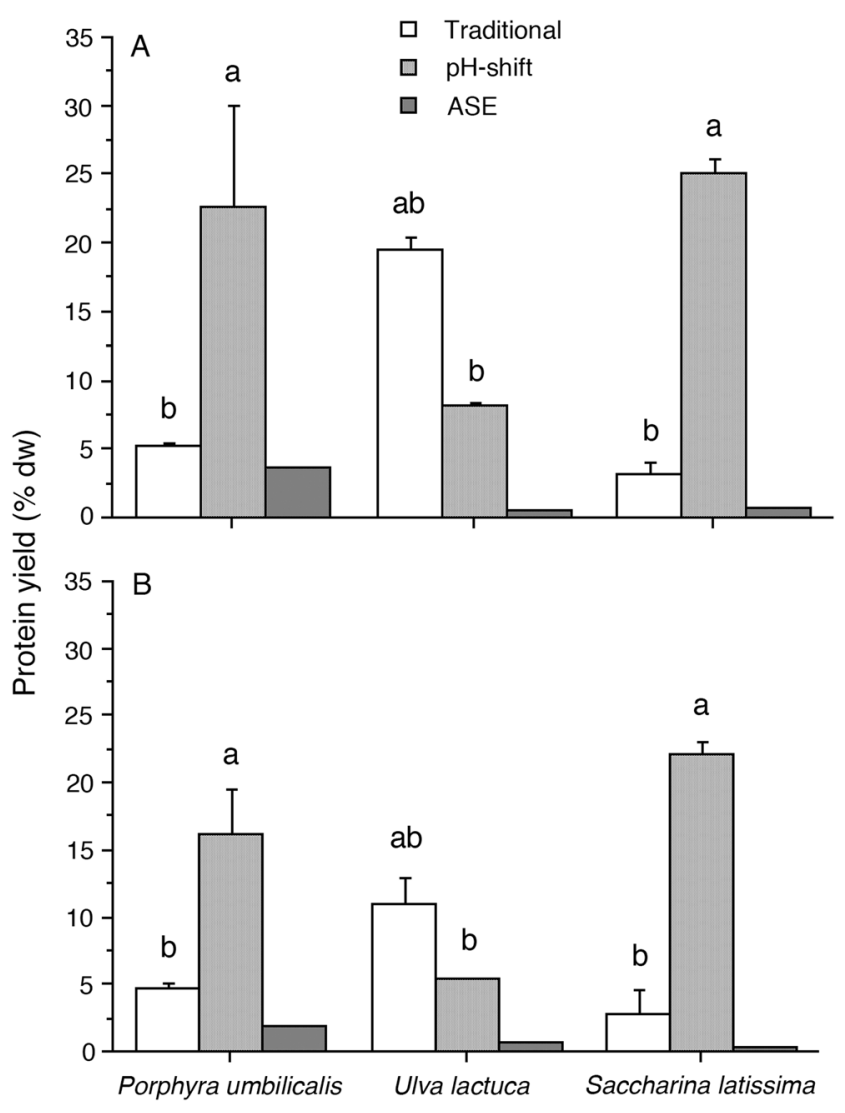

Fig. 3 Total protein yield, analyzed with $\mathbf{a}$ the Lowry method and $\mathbf{b}$ as total amino acids, for extracts from Porphyra umbilicalis, Ulva lactuca, and Saccharina latissima generated with the traditional method, the $\mathrm{pH}-$ shift method, and the accelerated solvent extraction (ASE) method. Letters above bars indicate significant differences based on the StudentNewman-Keuls procedure. Error bars show SEM $(n=2)$. Only one extract was obtained using the ASE method $(n=1)$ and, therefore, no error bars are presented and the results were not included in the statistical analysis

lower in extracts generated compared to those of their respective crude seaweeds, while the ash content was highly concentrated in the extracts made with this method, for $P$. umbilicalis, 2.0 times greater; for U. lactuca, 1.97 times greater; and for $S$. latissima, 1.36 times greater.

\section{Amino acids of seaweed biomass and extracts}

Total amino acids, when expressed on a dw basis, differed significantly (SNK, $p<0.05$ ) between the three crude seaweed species and were ranked P. umbilicalis $(31.8 \pm$ $1.7 \%)>$ U. lactuca $(19.6 \pm 0.6 \%)>$ S. latissima $(10.1 \pm$ $0.2 \%)$. All the three seaweed species contained all the analyzed essential amino acids (EAA) histidine, isoleucine, leucine, lysine, methionine, phenylalanine, threonine, valine, and tyrosine, and they contributed to 39,39 , and $42 \%$ of the total amino acids for $P$. umbilicalis, U. lactuca, and S. latissima, respectively. Generally, the distribution of amino acids (Table 3) was quite similar in all three seaweed species. The most abundant amino acids were glycine, alanine, asparagine, leucine, and glutamate, with some internal differences in the order.

The total amount of amino acids in the produced extracts when expressed on a dw basis was for all three species highest when using the $\mathrm{pH}$-shift technique. The achieved values here were $P$. umbilicalis $71.0 \pm 3.7 \%$, U. lactuca $51.2 \pm 2.1 \%$, and S. latissima $40.7 \pm 0.5 \%$ (Fig. 4a), which is significantly (SNK, $p<0.05$ ) higher than the amount of total amino acids in their respective crude seaweed biomasses. Out of the total amino acids, 42, 42, and $43 \%$ were EAA in the pH-shiftproduced extracts for $P$. umbilicalis, $U$. lactuca, and $S$. latissima, respectively (Table 3). This corresponds to 30, 22, and $17 \%$ of the weight of respective extract (dw basis).

Neither the traditional method nor the ASE® method concentrated the amino acids compared to the crude biomass. In fact, the total amino acid content in the extracts made with both the traditional method and the ASE® method was significantly lower than in their corresponding crude biomass (SNK, $p<0.05$ ).

\section{Fatty acids of seaweed biomass and extracts}

The $\mathrm{pH}$-shift technique concentrated fatty acids (Fig. 4b) for both U. lactuca and S. latissima and the total fatty acid content in those extracts $(5.0 \pm 0.4 \%$ and $3.3 \pm 0.2 \%$ on a dw basis, respectively) was significantly (SNK, $p<0.05$ ) higher than that in their corresponding crude biomasses $(2.3 \pm 0 \%$ and $2.1 \pm 0.4 \%$ of the dw, respectively) (Fig. 4b). However, there was no significant difference (SNK, $p>0.05$ ) in the total fatty acid content between the $\mathrm{pH}$-shift-produced extract and the crude biomass for P. umbilicalis (Fig. 4b). Overall, the total fatty acid content of all the traditionally made extracts and all the ASE extracts was significantly (SNK, $p<0.05$ ) lower than that in their corresponding crude biomasses.

The fatty acids (Table 4) of both $U$. lactuca and S. latissima biomasses were more evenly distributed compared to those in P. umbilicalis where three fatty acids (C20:5 n3 (EPA), C16:0, and $\mathrm{C} 20: 3 \mathrm{n} 6$ ) dominated and together constituted $82.8 \%$ of the total fatty acids.

EPA constituted $44.0 \pm 0.0 \%$ of the total fatty acids in $P$. umbilicalis, corresponding to $1.1 \%$ of the $\mathrm{dw}$. Thereafter, the most abundant fatty acids were $\mathrm{C} 16: 0$ and $\mathrm{C} 20: 3 \mathrm{n} 6$, which constituted $22.7 \pm 0.0 \%$ and $16.1 \pm 0.1 \%$ of the total amount of fatty acids, respectively. Those three fatty acids were also the most abundant ones in the three P. umbilicalis protein extracts. However, the order among them then changed.

The most abundant fatty acid in $U$. lactuca biomass was C18:3 n3, i.e., $\alpha$-linolenic acid (ALA), constituting 25.0 \pm $0.9 \%$ of the total fatty acids, which corresponds to $0.58 \%$ of the dw. Thereafter, the most abundant fatty acids were $\mathrm{C} 16: 0$, C16:4 n3, and 18:4 n3, constituting 19.1 $\pm 0.9 \%, 13.3 \pm 1.3 \%$, and $12.6 \pm 0.4 \%$ of the total fatty acids, respectively. Only 1.1 $\pm 0.1 \%$ of the fatty acids in $U$. lactuca was EPA. Also, for $U$. 

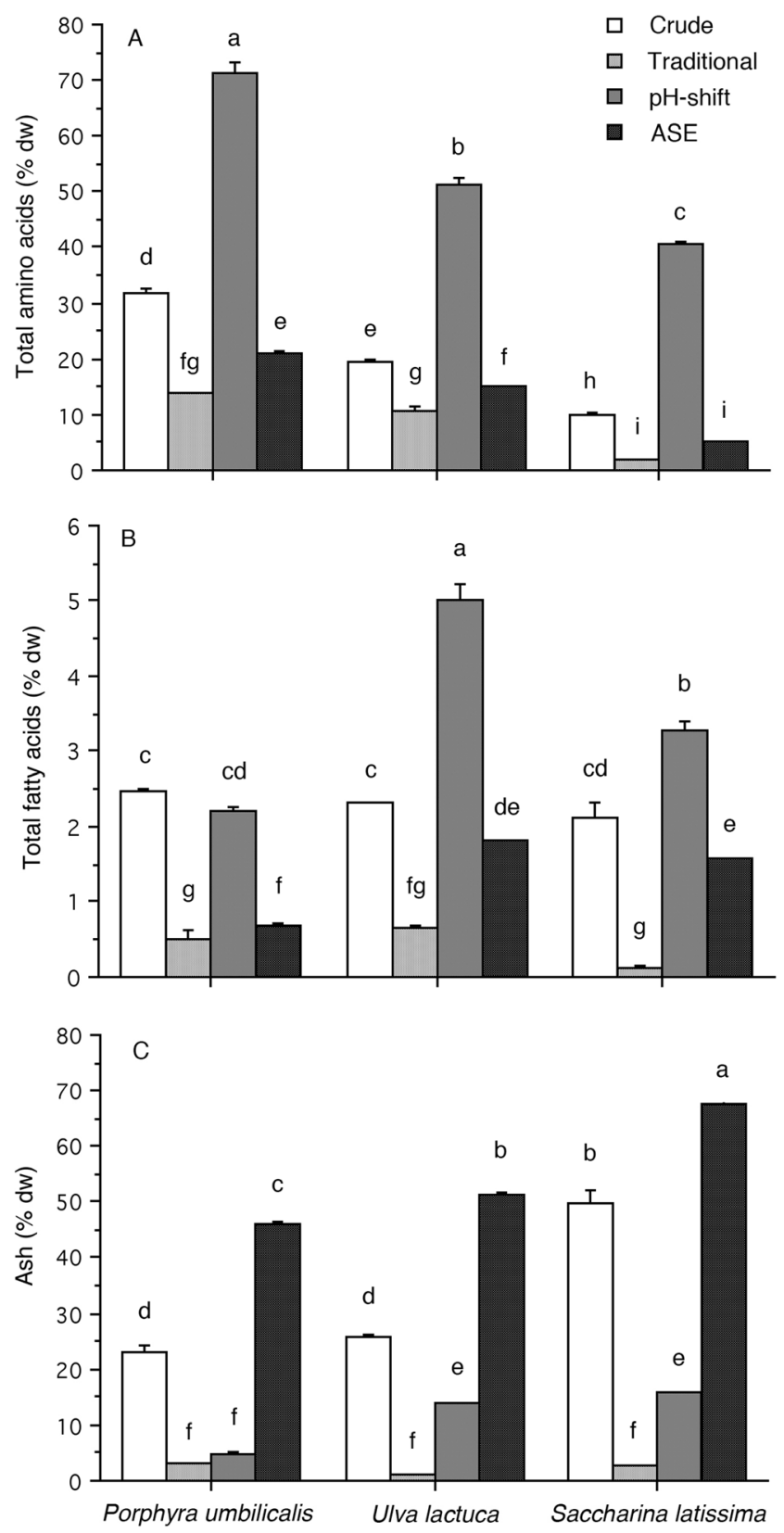

Fig. 4 a Total amino acids, $\mathbf{b}$ total fatty acids, and $\mathbf{c}$ ash content (\% dw) of the three seaweed species (Porphyra umbilicalis, Ulva lactuca, and Saccharina latissima) measured in crude seaweed material, as well as in extracts obtained with three different methods (traditional, $\mathrm{pH}$-shift, and ASE). Letters above bars indicate significant differences based on the Student-Newman-Keuls multiple comparison test. Error bars show $+\operatorname{SEM}(n=3)$

lactuca, the same fatty acids being the most abundant in the crude biomass were the most abundant ones in the extracts, with some minor changes in the ranking order. In contrast to $P$. umbilicalis and $S$. latissima (see below), U. lactuca biomass and its extracts contained docosapentaenoic acid (DPA), $22: 5 \mathrm{n} 3$ in low amounts.

The four most abundant fatty acids in the $S$. latissima biomass were $\mathrm{C} 20: 5 \mathrm{n} 3, \mathrm{C} 18: 4 \mathrm{n} 3, \mathrm{C} 16: 0$, and $\mathrm{C} 20: 4 \mathrm{n} 6$, constituting $18.9 \pm 1.6 \%, 18.4 \pm 0.7 \%, 16.8 \pm 1.2 \%$, and $14.1 \pm 0.9 \%$ of the total amount fatty acids, respectively. However, in the S. latissima extracts, C16:0 was concentrated in favor of ALA and EPA. Also, C18:1 was concentrated in all the S. latissima extracts compared to the crude biomass. ALA constituted $8.5 \pm 0.5 \%$ of the total fatty acid in crude $S$. latissima, but was lower in all extracts.

For all extracts from all three seaweed species, the relative amount of C16:0 was higher in the extracts compared to that in their corresponding crude seaweeds. Worth noting is that the fatty acid C20:0 was detected in all extracts from $P$. umbilicalis and $U$. lactuca, and in the $\mathrm{pH}$-shift extract from S. latissima but in neither of the crude seaweeds.

\section{Ash of seaweed biomass and extracts}

The lowest ash content (Fig. 4c) was found in the extracts generated using the traditional method, and the levels here were significantly (SNK, $p<0.05$ ) lower than those in their corresponding seaweeds. Also, the $\mathrm{pH}$-shift-produced extracts had significantly (SNK, $p<0.05$ ) lower ash content than the whole biomass. In contrast, the ash content in the ASE®-produced protein extracts was significantly $(\mathrm{SNK}, p<0.05)$ higher than that in their respective crude seaweeds. The ASE®-generated protein extracts contained $46.3 \pm 0.6 \%$, $51.3 \pm 0.7 \%$, and $67.7 \%$ ash on a dw basis for P. umbilicalis, $U$. lactuca, and $S$. latissima (single analysis), respectively, compared to $23.2 \pm 1.8 \%, 26.0 \pm 0.7 \%$, and $49.6 \pm 4.3 \%$ ash $\mathrm{dw}$ in their respective crude biomasses.

\section{Discussion}

Following a systematic comparison of three different methods for extracting and concentrating proteins from a red, a green, and a brown seaweed species, this study illustrates that there are clear species differences regarding the response to different extraction principles, both in terms of protein yield, final protein concentration of extracts, and co-extraction of nonprotein compounds. A secondary finding of the study was also that the protein analysis method affected the results more than expected, illustrating the challenge of measuring proteins in complex matrices like seaweeds which are rich, e.g., in pigments, carbohydrates, and salts.

\section{Differences in protein yield determined using the Lowry method and analyses of total amino acids}

Protein yields obtained in this study varied depending on the analysis method used (Lowry versus total amino acids) in accordance with a recent review paper by Maehre et al. (2018). However, the internal order between the different species/process method combinations was kept regardless of 
Table 3 Amino acid profile of crude seaweeds and seaweed-derived protein extracts ( $\%$ of total amount amino acids)

\begin{tabular}{|c|c|c|c|c|c|c|c|c|c|c|c|c|}
\hline & \multicolumn{4}{|c|}{ Porphyra umbilicalis } & \multicolumn{4}{|c|}{ Ulva lactuca } & \multicolumn{4}{|c|}{ Saccharina latissima } \\
\hline & Crude & Traditional & pH-shift & $\mathrm{ASE}^{\mathrm{a}}$ & Crude & Traditional & pH-shift & $\mathrm{ASE}^{\mathrm{b}}$ & Crude & Traditional & pH-shift & $\mathrm{ASE}^{\mathrm{a}}$ \\
\hline Gly & $5 \pm 0.5$ & $13.6 \pm 0.3$ & $10.6 \pm 0.7$ & $10.8 \pm 0.4$ & $.8 \pm 0.3$ & $11.4 \pm 0.9$ & $10.6 \pm 0.5$ & 8.9 & $10 \pm 0.1$ & $13.4 \pm 0.5$ & $11.2 \pm 0.6$ & $11.2 \pm 0.1$ \\
\hline Ala & $2 \pm 0.1$ & $7.9 \pm 0.2$ & $6.9 \pm 0.0$ & $13.7 \pm 0.7$ & $8.4 \pm 0.2$ & $7.2 \pm 0.3$ & $6.7 \pm 0.0$ & 3.0 & $7.7 \pm 0.2$ & $8.0 \pm 0.1$ & $6.3 \pm 0.1$ & $7.1 \pm 0.1$ \\
\hline Ser & \pm 0.1 & $3.8 \pm 0.3$ & $3.9 \pm 0.0$ & $1.8 \pm 0.1$ & $4.5 \pm 0.0$ & $3.6 \pm 0.1$ & $3.8 \pm 0.0$ & 1.4 & $3.8 \pm 0.0$ & $3.5 \pm 0.1$ & $3.6 \pm 0.0$ & $3.9 \pm 0.0$ \\
\hline Pro & $0 \pm 0.0$ & $4.3 \pm 0.0$ & \pm 0.1 & $0.7 \pm 0.0$ & $4.4 \pm 0.0$ & $3.8 \pm 0.2$ & $3.7 \pm 0.1$ & 39.6 & $4.9 \pm 0.0$ & $4.5 \pm 0.1$ & $4.0 \pm 0.0$ & $4.0 \pm 0.0$ \\
\hline Val & $7 \pm 0.1$ & $6.5 \pm 0.1$ & $6.2 \pm 0.1$ & $0.6 \pm 0.0$ & $6.1 \pm 0.1$ & $6.7 \pm 0.1$ & $6.3 \pm 0.1$ & 1.2 & $5.6 \pm 0.1$ & & $5.8 \pm 0.0$ & $2.8 \pm 0.0$ \\
\hline Nval & $0.6 \pm 0.1$ & $0.8 \pm 0.1$ & $8 \pm 0.0$ & $0.8 \pm 0.0$ & $1.0 \pm 0.1$ & $1.0 \pm 0.3$ & $1.3 \pm 0.0$ & 0.7 & $2.4 \pm 0.1$ & $0.5 \pm 0.0$ & $1.7 \pm 0.0$ & $2.8 \pm 0.0$ \\
\hline Thr & $5.3 \pm 0.1$ & $4.9 \pm 0.1$ & $4.7 \pm 0.0$ & $4.4 \pm 0.2$ & $5.2 \pm 0.1$ & $5.4 \pm 0.3$ & $5 \pm 0.1$ & 1.2 & $3.8 \pm 0.1$ & $5.1 \pm 0.1$ & $4.7 \pm 0.1$ & $4.2 \pm 0.0$ \\
\hline Cys & $1.4 \pm 0.2$ & $1.5 \pm 0.3$ & $2.4 \pm 0.1$ & $1.6 \pm 0.0$ & $2.5 \pm 0.2$ & $2 \pm 0.2$ & $1.9 \pm 0.1$ & 0.9 & $3.3 \pm 0.2$ & $1.2 \pm 0.1$ & $2.3 \pm 0.0$ & $3.9 \pm 0.0$ \\
\hline $\mathrm{Tau}^{\mathrm{c}}$ & $2.8 \pm 0.3$ & $1.3 \pm 0.1$ & $2.3 \pm 0.1$ & & $1.6 \pm 0.2$ & $1.4 \pm 0.3$ & & 0.9 & $3.1 \pm 0.2$ & $0.7 \pm 0.1$ & $2.2 \pm 0.0$ & $3.7 \pm 0.0$ \\
\hline Нур & n.d. & $0.1 \pm 0.1$ & $0.3 \pm 0.0$ & $0.1 \pm 0.0$ & $1.0 \pm 0.1$ & $0.5 \pm 0.2$ & $0.4 \pm 0.0$ & 1.3 & $0.5 \pm 0.1$ & n.d. & $0.3 \pm 0.1$ & $0.7 \pm 0.0$ \\
\hline Ile & $3.4 \pm 0.1$ & $4.1 \pm 0.1$ & $4.3 \pm 0.1$ & $0.3 \pm 0.0$ & $4.3 \pm 0.1$ & $5.2 \pm 0.3$ & $4.9 \pm 0.1$ & 0.8 & $5.1 \pm 0.2$ & $5.7 \pm 0.2$ & $4.8 \pm 0.1$ & $2.2 \pm 0.0$ \\
\hline Leu & $6.6 \pm 0.1$ & $7.0 \pm 0.1$ & $7.2 \pm 0.2$ & $0.3 \pm 0.0$ & $7.2 \pm 0.1$ & $7.3 \pm 0.1$ & $7.4 \pm 0.1$ & 0.9 & $7.6 \pm 0.3$ & $8.6 \pm 0.3$ & $7.1 \pm 0.1$ & $2.3 \pm 0.0$ \\
\hline Asn & $0.7 \pm 0.0$ & $0.7 \pm 0.2$ & $1.2 \pm 0.0$ & $0.4 \pm 0.1$ & $0.5 \pm 0.0$ & $0.6 \pm 0.3$ & $1.0 \pm 0.0$ & 0.3 & $1.5 \pm 0.1$ & n.d. & $1.1 \pm 0.0$ & $1.4 \pm 0.0$ \\
\hline Orn & n.d. & $0.3 \pm 0.3$ & $0.9 \pm 0.0$ & $0.2 \pm 0.0$ & n.d. & $0.2 \pm 0.4$ & $0.7 \pm 0.0$ & 0.4 & $1.3 \pm 0.1$ & n.d. & $0.9 \pm 0.0$ & $1.5 \pm 0.0$ \\
\hline Asp & $10.6 \pm 0.1$ & $10.0 \pm 0.3$ & $8.9 \pm 0.1$ & $28.0 \pm 1.0$ & $12.9 \pm 0.3$ & $13.1 \pm 1$ & $11.5 \pm 0.3$ & 5.2 & $8.3 \pm 0.2$ & $12.6 \pm 0.3$ & $9.9 \pm 0.1$ & $15.9 \pm 0$ \\
\hline Lsn & $7.3 \pm 0.2$ & $6.1 \pm 0.1$ & $5.3 \pm 0.1$ & $0.6 \pm 0.0$ & $3.3 \pm 0.5$ & $3.5 \pm 0.2$ & $4.3 \pm 0.3$ & 0.6 & $4.0 \pm 0.1$ & $6.7 \pm 0.1$ & $4.9 \pm 0.1$ & $1.9 \pm 0.0$ \\
\hline Gly & $1.2 \pm 0.1$ & $1.1 \pm 0.2$ & $1.9 \pm 0.0$ & $1.3 \pm 0.0$ & $2.0 \pm 0.2$ & $1.6 \pm 0.1$ & $1.5 \pm 0.0$ & 0.7 & $2.6 \pm 0.1$ & $0.9 \pm 0.1$ & $1.8 \pm 0.0$ & $3.1 \pm 0.0$ \\
\hline Glu & $8.9 \pm 0.5$ & $6.5 \pm 0.2$ & $6.5 \pm 0.1$ & $23.0 \pm 2.6$ & $10.6 \pm 0.2$ & $7.9 \pm 0.5$ & $8.5 \pm 0.2$ & 25.9 & $7.5 \pm 0.1$ & $9.0 \pm 0.1$ & $8.5 \pm 0.1$ & $15.8 \pm 0.1$ \\
\hline Met & $0.3 \pm 0.1$ & $1.0 \pm 0.1$ & $1.0 \pm 0.0$ & n.d. & $1.2 \pm 0.0$ & $1.3 \pm 0.1$ & $1.0 \pm 0.1$ & 0.1 & $1.3 \pm 0.1$ & $1.0 \pm 0.0$ & $2.0 \pm 0.0$ & $0.5 \pm 0.0$ \\
\hline His & $0.5 \pm 0.1$ & $1.4 \pm 0.6$ & $2.2 \pm 0.0$ & $0.3 \pm 0.0$ & $0.3 \pm 0.1$ & $1.4 \pm 0.7$ & $2.2 \pm 0.0$ & 0.6 & $2.4 \pm 0.1$ & $0.6 \pm 0.1$ & $2.1 \pm 0.0$ & $2.2 \pm 0.0$ \\
\hline Phe & $4.2 \pm 0.2$ & $4.3 \pm 0.2$ & $4.3 \pm 0.0$ & $0.2 \pm 0.0$ & $4.9 \pm 0.1$ & $5 \pm 0.3$ & $5.2 \pm 0.1$ & 0.7 & $5.0 \pm 0.1$ & $5.6 \pm 0.2$ & $4.5 \pm 0.1$ & $2.3 \pm 0.0$ \\
\hline Arg & $5.9 \pm 0.3$ & $8.6 \pm 0.2$ & $8.3 \pm 0.1$ & $0.8 \pm 0.1$ & $2.8 \pm 0.1$ & $5.6 \pm 0.6$ & $6.1 \pm 0.1$ & 3.8 & $4.7 \pm 0.1$ & $4.2 \pm 0.3$ & $6.1 \pm 0.2$ & $3.3 \pm 0.0$ \\
\hline Tyr & $3.8 \pm 0.1$ & $4.2 \pm 0.2$ & $4.8 \pm 0.1$ & $1.1 \pm 0.0$ & $3.7 \pm 0.2$ & $4.2 \pm 0.1$ & $4.1 \pm 0.2$ & 0.9 & $3.7 \pm 0.1$ & $2.0 \pm 0.9$ & $4.4 \pm 0.1$ & $3.2 \pm 0.0$ \\
\hline$\sum$ EAA & 38.5 & 41.0 & 42.4 & 9.4 & 38.7 & 42.0 & 42.3 & 7.9 & 41.8 & 42.7 & 42.6 & 25.5 \\
\hline
\end{tabular}

EAA essential amino acids, $n . d$. non detectable

${ }^{a}$ Analysis was performed in duplicate

${ }^{\mathrm{b}}$ Analysis was performed on a single sample

${ }^{\mathrm{c}}$ Not strictly an amino acid, it is a sulfonic acid

analysis method. For all combinations, with the exception of the $U$. lactuca ASE® extract, the yield was greater when data obtained with the Lowry method was used for calculations. For $P$. umbilicalis and $U$. lactuca crude biomass, both protein analysis methods gave similar protein levels; however, in the extracts, the Lowry method gave higher protein levels than total amino acids. This probably explains the higher protein yields obtained when using Lowry data to calculate the yields. For S. latissima, the protein levels of both the crude biomass and the extracts were higher when recorded using the Lowry method compared to those obtained with the total amino acid analysis method, resulting in more similar protein yield values with both analysis methods. Both the pigment content and the type of amino acids present (Legler et al. 1985) could affect the total protein results found using the Lowry method. Selective retention of certain amino acids and pigments in the extracts could affect the measured values recorded. The total amino acid method is more robust to such compositional differences and is generally used as a reference method when compiling nitrogen-to-protein conversion factors (i.e., Lourenço et al. 2002, Biancarosa et al. 2017). The amino acid method used in this study, however, lacks the ability to detect tryptophan which may result in a slight underestimation of the total amount of amino acids. According to the review of Fleurence (1999), tryptophan values of $0.3-3.0 \%$ of the total proteins have been reported for seaweeds.

\section{Protein yield as a function of extraction method and species}

Compared with earlier reports, the protein yield obtained with the traditional method for U. lactuca (19.6 and 10.9\% with Lowry and total amount amino acids, respectively) was lower than that reported by Wong and Cheung (2001), where 36\% protein yield was reported. In contrast to the traditional extraction method in the present study, Wong and Cheung (2001) 


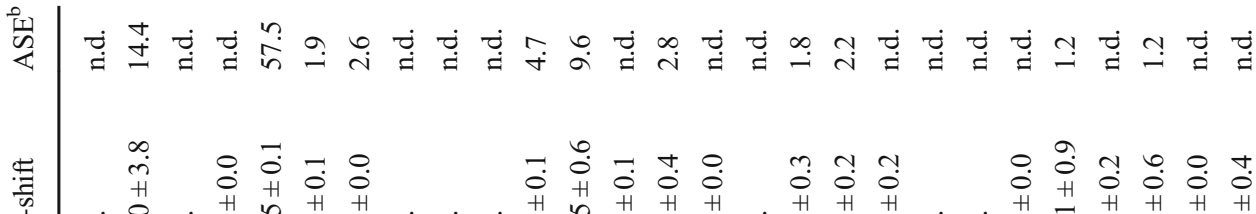

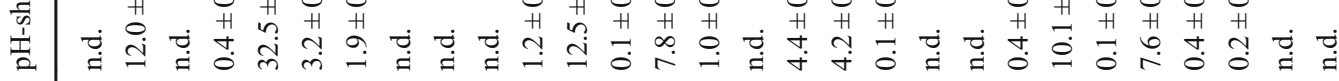

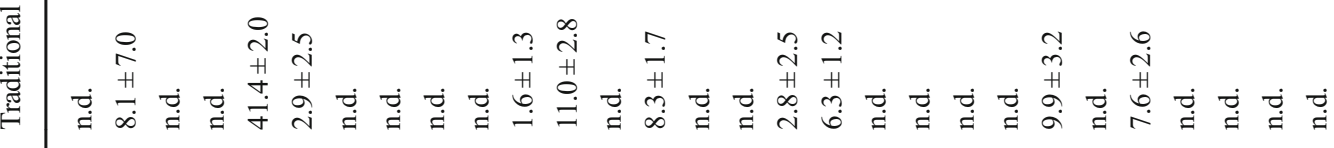

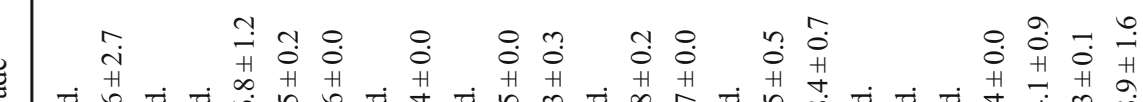

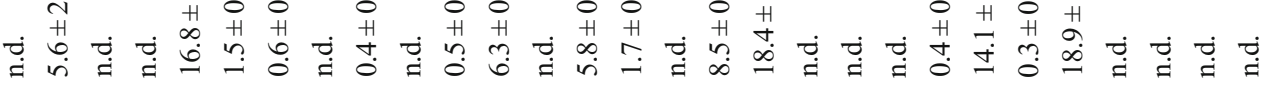

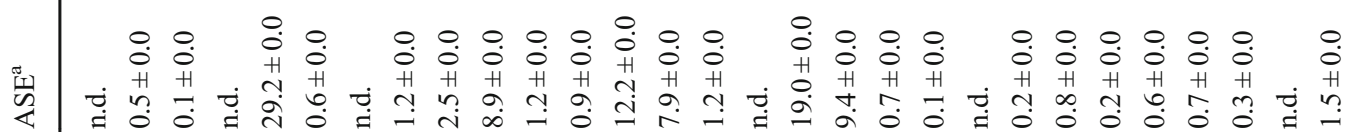

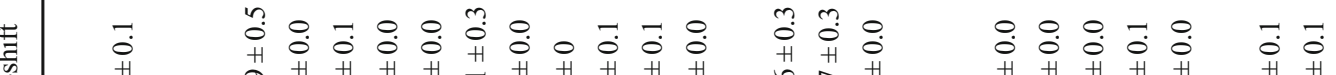

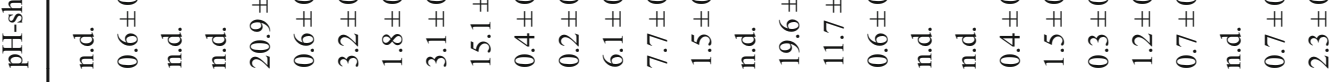

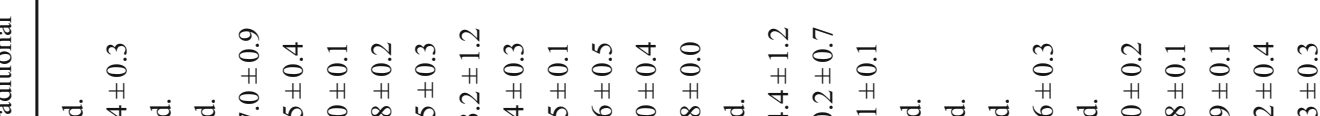

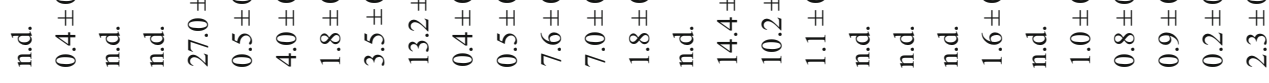

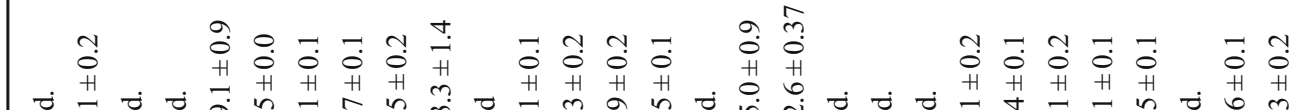

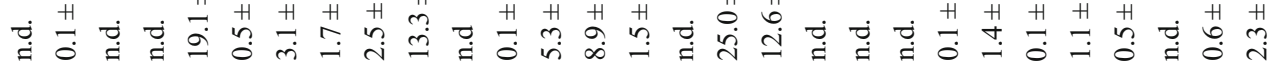

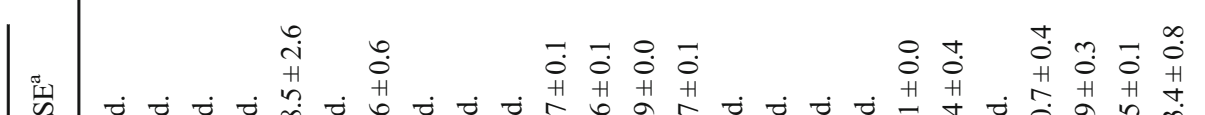

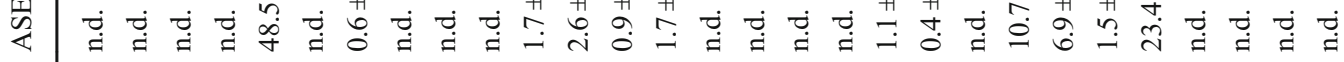

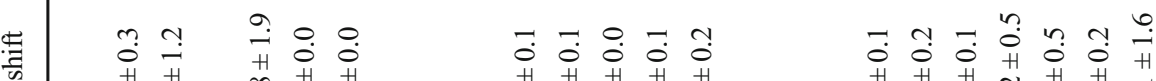

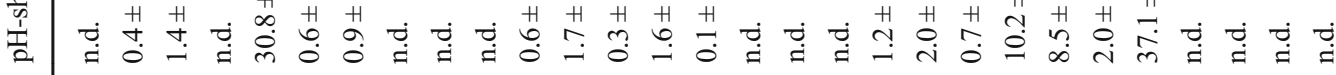

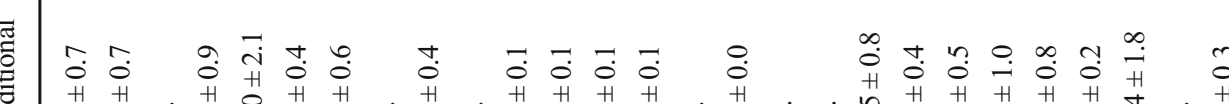

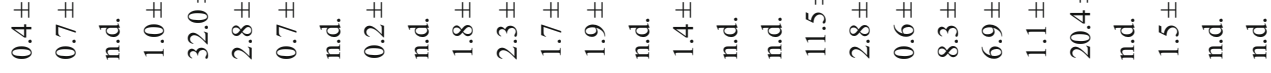

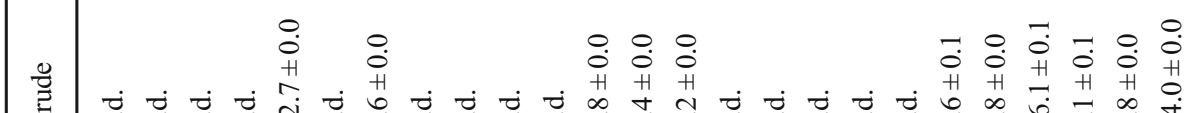

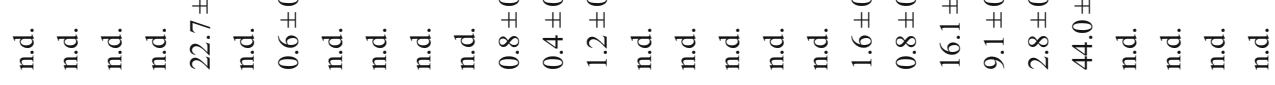

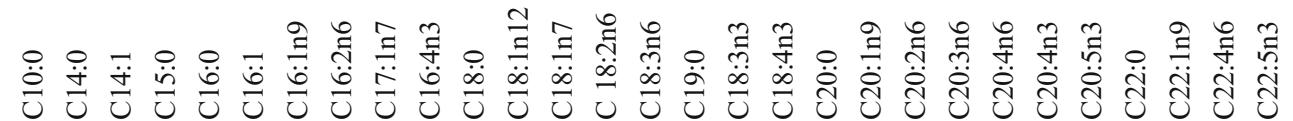

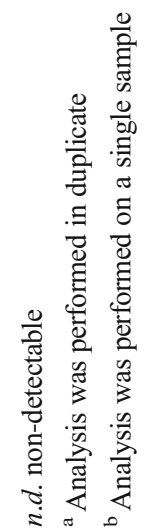


added 2-mercaptoethanol, to increase the final yield, when resuspending the pellet, something which removes food grade classification (Garcia-Vaquero et al. 2017). In addition, the $\mathrm{pH}$ was increased to $\mathrm{pH} 12$ in this study (Wong and Cheung 2001) before ammonium sulfate precipitation was performed, and furthermore the residue was re-extracted five times instead of two, as was done here. Many other studies have examined the extraction of proteins from a variety of seaweed species, beyond those addresses in the present study, using variations of the traditional method (i.e., Wong and Cheung (2001), Kandasamy et al. (2012), Suresh Kumar et al. (2014) and Garcia-Vaquero et al. (2017)). However, since both compositional and structural differences between different seaweed species are substantial, direct comparisons of results are difficult.

To date, with the exception of the study carried out by Veide Vilg and Undeland (2017), nobody has reported values on seaweed protein yield using the $\mathrm{pH}$-shift method or the ASE® method. Veide Vilg and Undeland (2017) only studied S. latissima, and in comparison with that study, the protein yield obtained here for S. latissima was higher (25\% when assessed using the Lowry measurements versus $16 \%$ in their study). The latter (Veide Vilg and Undeland 2017) was, however, achieved when using a lower water to biomass ratio of $5.56: 1(v / w)$ than the one used here $6: 1(v / w)$. It has clearly been shown how the addition of more water to the biomass (increased ratio of water/biomass) improves yield (Vareltzis and Undeland 2012, Veide Vilg and Undeland 2017) since the solubility of proteins is facilitated, and since the fractions removed during the $\mathrm{pH}$-shift process become less concentrated. Also, Veide Vilg and Undeland (2017) did not apply a freeze-thawing step during the protein precipitation, the latter which was shown in this work to enhance precipitation for $P$. umbilicalis, U. lactuca, and S. latissima by 8,4 , and 14 percentage points, respectively. In terms of scaling up the $\mathrm{pH}-$ shift technique in an environmentally friendly manner, however, use of as low water volumes as possible and a minimum number of process steps is desirable which pin points a tradeoff between scalability and efficiency during protein extraction. The costs for extra steps should be carefully weighed against the final value of the protein extract.

The "bio-refinery approach" using ASE® gave low total protein yields, especially for U. lactuca and S. latissima. Also, those extracts had lower protein concentrations than their respective crude biomasses. The reason for this may be explained by the fact that phlorotannins or phenols present in the raw seaweed biomass, that are removed during the second step of the ASE® method, bind to proteins and therefore also proteins were removed in the phlorotannin extraction step of the method. However, the fact that a lipid, a tannin/polyphenol, and a protein extract can be independently generated in a sequential manner is a positive attribute for this method. The extractability of proteins using both the $\mathrm{pH}$-shift method and the ASE $®$ method was higher for the red species $(P$. umbilicalis) than that for the green species (U. lactuca) which has also been seen by Wong and Cheung (2001). However, for the traditional extraction method, the opposite was seen. Regarding the brown species S. latissima, the extractability with the different methods was ranked as $\mathrm{pH}$-shift $>$ traditional $>$ ASE®, the same order as for P. umbilicalis. However, the protein yield obtained for P. umbilicalis (4.1\%) using ASE® was noticeably higher than that for S. latissima $(0.7 \%)$. This clearly points to the diversity among different seaweed species regarding their response to different solvents, chemicals, and physical treatments. The cell wall differs between different seaweed species (Joubert and Fleurence 2008; Hurd et al. 2014), which could explain the variation in extractability between the three species. Also, the abundance and type of phenolic compounds vary largely (Sabeena Farvin and Jacobsen 2013), with the phlorotannins being exclusively found in the brown seaweed (Hurd et al. 2014), something which could explain the extremely low protein yield achieved when applying the ASE® method to S. latissima. Also, the ability of phlorotannins to precipitate proteins is $\mathrm{pH}$-dependent (Stern et al. 1996). Precipitation of proteins caused by phlorotannins from either the brown seaweed Ecklonia radiata or the brown seaweed Carpophyllum maschalocarpum was highest between pH 2 and 7 (Stern et al. 1996). With the assumption that all phlorotannins have maximum precipitation ability at neutral, or acidic pHs, it is likely that this ability of phlorotannins will not affect the solubility of the protein in the first step of the $\mathrm{pH}$-shift process. However, the appearance of phlorotannins could be an advantage in terms of the isoelectric precipitation step of the process. The presence of phlorotannins in the final extracts might, however, result in a bitter tasting protein extract, which should be evaluated in future studies.

\section{Composition of protein extracts}

The traditional method resulted in extracts with lower protein, ash, and total fatty acid content than their respective crude seaweeds. This indicates that the traditional method mainly concentrates the carbohydrates present in the raw material. The initial water extraction of proteins was probably poor since the adaption of the $\mathrm{pH}$-shift process showed that the solubility of seaweed proteins at its native $\mathrm{pH}$ in water is only $\sim 35 \%$ (Fig. 2).

Also with the ASE® method, the protein content and fatty acid content were lower in the resultant extracts compared to those of their respective crude seaweeds, while the ash content was highly concentrated. The initial de-fatting step explains the lower fat contents found and, as stated earlier, it is likely that the proteins were bound to, and removed together with the phlorotannins or phenols in the second extraction step of this method. 


\section{Amino acid profile}

A crucial factor for all protein extracts is their nutritional value, i.e., their amino acid profile as well as the presence of other nutrients and tentative anti-nutrient factors, such as phenolic compounds, dietary fibers, or for example, trypsin inhibitors that could reduce the protein digestibility. In comparison to our study, none of the earlier mentioned studies, with the exception of the work carried out by Wong and Cheung (2001) and Garcia-Vaquero et al. (2017), have analyzed the amino acid profile of seaweed protein extracts, and none have analyzed the fatty acid pattern.

The amino acid analysis method used in this study lacks the ability to detect tryptophan; otherwise, all other essential amino acids were found in the three seaweed species examined (Table 3).

In the three $\mathrm{pH}$-shift-produced protein extracts, the relative amount of EAA on a protein and dw basis $(42-43 \%$ and $17-$ $30 \%$, respectively) was comparable to the values reported for soy flour, $40-48 \%$ on a protein basis and $15-24 \%$ on a $\mathrm{dw}$ basis (USDA Food Composition Databases 2018a; Friedman and Brandon 2001), respectively. Compared to egg white, which has $48 \%$ EAA on a protein basis and $39 \%$ on a dw basis (USDA Food Composition Databases 2018b), the seaweed extracts had somewhat lower values.

The reported relative amounts of EAA in the concentrates from Hypnea charoides, Hypnea japonica and U. lactuca produced by Wong and Cheung (2001) were slightly lower than the relative amounts found both in our $\mathrm{pH}$-shiftproduced and traditionally made extracts, and ranged between 36.2 and $40.2 \%$ of the total amino acids. Also, the relative amounts of EAA of a traditionally made protein extract from the brown seaweed Himanthalia elongata was slightly lower, 39.5\% (Garcia-Vaquero et al. 2017) compared to the levels in our study.

It is recommended for adults that $11.1 \%$ of the protein should consist of EAA (Damodaran 2008), which here was fulfilled by all the crude seaweed biomasses, and also by all extracts, except for ASE® extracts generated from $P$. umbilicalis and U. lactuca. It should be stressed, however, that on a dw basis, the $\mathrm{pH}$-shift-produced extracts gave several times more EAA than the traditional extracts; for $P$. umbilicalis, 5.3 times greater; for U. lactuca, 4.8 times greater; and for S. latissima, 20.9 times greater.

In the review by Friedman and Brandon (2001), it is stated that soy flour is deficient in methionine, since it only has methionine present at concentrations of $0.47-0.65 \%$ (dw) of the soy flour (USDA Food Composition Databases 2018a; Friedman and Brandon 2001). The corresponding numbers for methionine in the $\mathrm{pH}$-shift-produced extracts were $0.71,0.51$, and $0.82 \%$ on a dw basis for P. umbilicalis, $U$. lactuca, and $S$. latissima, respectively, showing that seaweed-derived protein extracts may be a better source of methionine than soy meal, even if methionine and histidine were the two least abundant EAAs detected in the extracts generated with this method. Due to the sometimes coreported values of methionine plus cysteine (since cysteine is a product of methionine (WHO 2002)), a comparison between studies and recommended values is obstructed. However, the recommended values for adults include that $1.7 \%$ of the proteins consumed should consist of methionine and cysteine together. The methionine and cysteine contents together compose $6.81 \%$ (Friedman and Brandon 2001) of the total proteins in soy. In the $\mathrm{pH}$-shiftproduced extracts from $P$. umbilicalis, $U$. lactuca and $S$. latissima, methionine and cysteine together constituted $3.4,2.9$, and $4.3 \%$ of the total amino acids present, respectively, which corresponds to $2.4,1.5$, and $1.8 \%$ of the extracts on a dw basis. Thus, for seaweed, as for other plantbased proteins (Friedman 1996), methionine seems to be the limiting EAA, even if levels of cysteine compensate for the joint values of methionine and cysteine.

Regarding histidine, the recommended value for adults is $1.6 \%$ on a protein basis, which means that the recommended values are fulfilled for the $\mathrm{pH}$-shift-produced extracts from $P$. umbilicalis, U. lactuca and S. latissima, which contained 2.2, 2.2 , and $2.1 \%$ histidine on a protein basis, respectively. The recommended values were, however, not fulfilled by the crude P. umbilicalis or $U$. lactuca biomass.

The relative quantity of glutamate, the amino acid giving rise to the typical umami taste (Yamaguchi and Ninomiya 2000; Ikeda 2002), ranged from $\sim 8-11 \%$ of total amino acids in the crude seaweeds, and approximately the same relative abundance was seen in the traditionally produced $(\sim 7-9 \%)$ and the pH-shift-produced protein extracts $(\sim 7-9 \%)$. However, glutamate was highly concentrated in the ASE® protein extracts and in those extracts, glutamate constituted 23\% (P. umbilicalis), $26 \%$ (U. lactuca), and $16 \%$ (S. latissima) of the total amount amino acids, corresponding to $4.9,3.9$, and $0.8 \%$ of the extracts on a dw basis, respectively. The high levels of both glutamate and ash (minerals) could make those extracts useful as alternative seasoning with a potential high umami taste.

\section{Fatty acid profile}

Co-extraction of other high-value food components such as fatty acids together with proteins is of high value for producing multi-functional protein extracts in the future. Provided they are maintained stable, the observed co-extraction of fatty acids along with proteins can be regarded an added value to the extracts when fatty acids are from the $\mathrm{n} 3$ series.

The content of EPA, one of the known health beneficial LC n3PUFAs (Lavie et al. 2009; Calder 2013), in the pHshift extract of $P$. umbilicalis $(0.8 \%$ on a dw basis) was around one third to one half the values found in fatty fish (herring and salmon) which according to the numbers 
from The National Food Agency database (2018a, b) contain $1.5 \%$ respectively $2.6 \% \mathrm{EPA}$ on a dw basis ( 0.42 and $1.02 \%$ on a ww basis). Functional health claims can be made on products containing down to $40 \mathrm{mg}$ $\mathrm{EPA}+\mathrm{DHA}$ per $100 \mathrm{~g}$ product. From a functional foods perspective (Siró et al. 2008), it is thus an advantage that the fatty acids are not separated to a large extent from the proteins during $\mathrm{pH}$-shift processing. However, both the lower amount of total fatty acids and the lower relative amount of EPA in the P. umbilicalis $\mathrm{pH}$-shift extract compared to crude $P$. umbilicalis result in that the crude $P$. umbilicalis biomass contained 1.3 times more EPA than the $P$. umbilicalis $\mathrm{pH}$-shift extract, $1.1 \%$ EPA on a dw basis. In $U$. lactuca and its extracts, EPA only constituted around $1 \%$ of the total fatty acids, but in contrast to $P$. umbilicalis, $U$. lactuca contained high levels of ALA, a precursor to the more beneficial long-chained $\mathrm{n} 3$ fatty acids. Also, in contrast to the $\mathrm{pH}$-shift extracts from $P$. umbilicalis and S. latissima, $2.3 \%$ of the fatty acids in the $\mathrm{pH}$-shift-produced extract from $U$. lactuca was docosapentaenoic acid (DPA), corresponding to $0.12 \%$ of the dw. This is more than double the amount (\% $\mathrm{dw}$ ) found in the crude U. lactuca biomass. A concentrating effect was thus seen, indicating that DPA could be bound to proteins in the seaweed. DPA is much less studied than EPA and DHA, but it is possessed that DPA has beneficial health effects (Kaur et al. 2011). Both the content of EPA and DPA, and in some cases DHA, which occasionally has been detected in S. latissima (Veide Vilg et al. 2015), thus make seaweeds and their protein extracts unique in comparison to agricultural crops and their products since land-based plants lack the natural ability to produce fatty acids with more than 18 carbons (Gill and Valivety 1997).

\section{Ash content}

Minerals, as estimated by ash, were largely reduced during the traditional process probably because of the desalting dialysis step. Also, the $\mathrm{pH}$-shift extracts had lower ash content than the whole biomasses, which is likely because of the dilution with water, i.e., salt is washed out during the process. However, the ASE® method was found to concentrate minerals in the resultant extracts. Together with the ability of the ASE® method to concentrate glutamate, the method could thus become useful as an alternative seasoning production method generating a product with high saltiness and umami taste. It should be stressed though that if there are potential heavy metals in the seaweed biomass, they will probably end up in this fraction. Worth to note is that no heavy metals were found in $P$. umbilicalis cultivated at the exact same destination as the biomasses used here (Wahlström et al. 2018). Of course, with any change in location of cultivation or species, both heavy metals and individual minerals need to be both determined and quantified.

\section{Conclusion}

This study showed that different species of seaweeds responded differently to the three protein extraction methods evaluated, but also, that some general trends could be seen. The traditional method gave the highest total protein yield for $U$. lactuca, but the protein concentration in all the extracts produced with this method was significantly lower than that recorded in their respective crude seaweeds. The same was also true for ash and total fatty acids, which were significantly lower than in their corresponding seaweed biomasses. This together with the time-consuming dialysis step and the high use of water might render upscaling of the traditional method difficult and unattractive for industry.

The ASE® technique concentrated the ash and glutamate content but resulted in extracts lower in both protein and lipid concentrations compared to their corresponding crude seaweeds. Therefore, those extracts would be interesting as salt replacers and/or umami enhancers, rather than as proteinenriching ingredients, with the abovementioned constraint.

The $\mathrm{pH}$-shift techniques' ability to significantly concentrate the proteins from all three seaweed species examined in this study and the fact that relatively high protein yields were achieved using this method make it a promising strategy for producing seaweed protein ingredients for food and feed use. The method has been scaled up with success for fish and other muscle sources, however, without the osmotic shock and freeze-induced precipitation steps. Future work still needs to be done to further increase the total protein yield achievable using this method and, for U. lactuca, to solve the problems reported here concerning the large variations in the precipitation step. Also, sensory evaluation and techno functionality testing of resulting extracts should be carried out to investigate their suitability as a potential food and/or feed ingredients.

Acknowledgements John Axelsson is thanked for help with examination of the effect of freezing during the $\mathrm{pH}$-shift process on $\mathrm{S}$. latissima.

Funding information The authors would like to thank the Swedish Foundation for Strategic Research (project no. 2820005) and the Swedish Research Council Formas (project no. 21210034) for funding this study.

Open Access This article is distributed under the terms of the Creative Commons Attribution 4.0 International License (http:// creativecommons.org/licenses/by/4.0/), which permits unrestricted use, distribution, and reproduction in any medium, provided you give appropriate credit to the original author(s) and the source, provide a link to the Creative Commons license, and indicate if changes were made. 


\section{References}

Aguilera-Morales M, Casas-Valdez M, Carrillo-Domínguez S, GonzálezAcosta B, Pérez-Gil F (2005) Chemical composition and microbiological assays of marine algae Enteromorpha spp. as a potential food source. J Food Compos Anal 18:79-88

Aiking H (2014) Protein production: planet, profit, plus people? Amer J Clin Nutr 100(Suppl 1):483S-489S

Alexandratos N, Bruinsma J (2012) World agriculture towards 2030/2050: the 2012 revision. ESA Working paper No. 12-03. Rome, FAO

Biancarosa I, Espe M, Bruckner C, Heesch S, Liland N, Waagbø, Torstensen B, Lock EJ (2017) Amino acid composition, protein content, and nitrogen-to-protein conversion factors of 21 seaweed species from Norwegian waters. J Appl Phycol 29:1001-1009

Calder PC (2013) Omega-3 polyunsaturated fatty acids and inflammatory processes: nutrition or pharmacology? Brit J Clin Pharmacol 75: 645-662

Cavonius LR, Carlsson NG, Undeland I (2014) Quantification of total fatty acids in microalgae: comparison of extraction and transesterification methods. Analyt Bioanalyt Chem 406: $7313-7322$

Černá M. (2011). Chapter 24-Seaweed proteins and amino acids as nutraceuticals. In: Se-Kwon K (ed) Marine medical foods: implications and applications, macro and microalgae, Academic Press, NY pp. 297-312

Cian RE, Fajardo MA, Alaiz M, Vioque J, González RJ, Drago SR (2014) Chemical composition, nutritional and antioxidant properties of the red edible seaweed Porphyra columbina. Int J Food Sci Nutr 65: 299-305

Damodaran S (2008) Amino acids, peptides, and proteins. In: Damodaran S, Parkin KL, Fennema OR (eds) Fennema's food chemistry, $4^{\text {th }}$ edn. CRC Press, New York, pp 217-330

Fleurence J (1999) Seaweed proteins: biochemical, nutritional aspects and potential uses. Trends Food Sci Technol 10:25-28

Fleurence J, Gutbier G, Mabeau S, Leray C (1994) Fatty acids from 11 marine macroalgae of the French Brittany coast. J Appl Phycol 6: $527-532$

Fleurence J, Le Coeur C, Mabeau S, Maurice M, Landrein A (1995) Comparison of different extractive procedures for proteins from the edible seaweeds Ulva rigida and Ulva rotundata. J Appl Phycol 7:577-582

Friedman M (1996) Nutritional value of proteins from different food sources. A review. J Agric Food Chem 44:6-29

Friedman M, Brandon DL (2001) Nutritional and health benefits of soy proteins. J Agric Food Chem 49:1069-1086

Fujiwara-Arasaki T, Mino N, Kuroda M (1984) The protein value in human nutrition of edible marine algae in Japan. In: Bird CJ, Ragan MA (eds), Eleventh International Seaweed Symposium: Proceedings of the Eleventh International Seaweed Symposium, Springer, Dordrecht pp 513-516

Galland-Irmouli AV, Fleurence J, Lamghari R, Luçon M, Rouxel C, Barbaroux O, Bronowicki JP, Villaume C, Guéant JL (1999) Nutritional value of proteins from edible seaweed Palmaria palmata (dulse). J Nutr Biochem 10:353-359

Garcia-Vaquero M, Lopez-Alonso M, Hayes M (2017) Assessment of the functional properties of protein extracted from the brown seaweed Himanthalia elongata (Linnaeus) S. F. Gray. Food Res Int 99:971978

Gill I, Valivety R (1997) Polyunsaturated fatty acids, part 1: occurrence, biological activities and applications. Trends Biotechnol 15:401-409

Herrero M, Sánchez-Camargo ADP, Cifuentes A, Ibáñez E (2015) Plants, seaweeds, microalgae and food by-products as natural sources of functional ingredients obtained using pressurized liquid extraction and supercritical fluid extraction. Trends Analyt Chem 71:26-38

Hurd CL, Harrison PJ, Bischof K, Lobban CS (2014) Seaweed ecology and physiology. Cambridge University Press, Cambridge

Ikeda K (2002) New seasonings. Chem Senses 27:847-849

Jordan P, Vilter H (1991) Extraction of proteins from material rich in anionic mucilages: partition and fractionation of vanadatedependent bromoperoxidases from the brown algae Laminaria digitata and L. saccharina in aqueous polymer two-phase systems. Biochim Biophys Acta Gen Subj 1073:98-106

Joubert Y, Fleurence J (2008) Simultaneous extraction of proteins and DNA by an enzymatic treatment of the cell wall of Palmaria palmata (Rhodophyta). J Appl Phycol 20:55-61

Kandasamy G, Karuppiah SK, Rao PVS (2012) Salt- and pH-induced functional changes in protein concentrate of edible green seaweed Enteromorpha species. Fish Sci 78:169-176

Kaur G, Cameron-Smith D, Garg M, Sinclair AJ (2011) Docosapentaenoic acid (22:5n-3): a review of its biological effects. Progr Lipid Res 50:28-34

Lavie CJ, Milani RV, Mehra MR, Ventura HO (2009) Omega-3 polyunsaturated fatty acids and cardiovascular diseases. J Am Coll Cardiol 54:585-594

Legler G, Müller-Platz CM, Mentges-Hettkamp M, Pflieger G, Jülich E (1985) On the chemical basis of the Lowry protein determination. Anal Biochem 150:278-287

Leigh EG, Paine RT, Quinn JF, Suchanek TH (1987) Wave energy and intertidal productivity. Proc Nat Acad Sci 84:1314-1318

Lopes G, Sousa C, Silva LR, Pinto E, Andrade PB, Bernardo J, Mouga T, Valentão P (2012) Can phlorotannins purified extracts constitute a novel pharmacological alternative for microbial infections with associated inflammatory conditions? PLoS One 7:e31145

Lourenço SO, Barbarino E, De-Paula JC, Pereira LOS, Marquez UML (2002) Amino acid composition, protein content and calculation of nitrogen-to-protein conversion factors for 19 tropical seaweeds. Phycol Res 50:233-241

Lowry OH, Rosebrough NJ, Farr AL, Randall RJ (1951) Protein measurement with the Folin phenol reagent. T J Biol Chem

Maehre HK, Malde MK, Eilertsen KE, Elvevoll EO (2014) Characterization of protein, lipid and mineral contents in common Norwegian seaweeds and evaluation of their potential as food and feed. J Sci Food Agric 94:3281-3290

Mæhre HK, Dalheim L, Edvinsen GK, Elvevoll EO, Jensen I-J (2018) Protein determination-method matters. Foods 7:5

Markwell MAK, Haas SM, Bieber LL, Tolbert NE (1978) A modification of the Lowry procedure to simplify protein determination in membrane and lipoprotein samples. Anal Biochem 87:206-210

Marmon SK, Undeland I (2010) Protein isolation from gutted herring (Clupea harengus) using pH-shift processes. J Ag Food Chem 58: 10480-10486

Matanjun P, Mohamed S, Mustapha NM, Muhammad K (2009) Nutrient content of tropical edible seaweeds, Eucheuma cottonii, Caulerpa lentillifera and Sargassum polycystum. J Appl Phycol 21:75-80

Ortiz J, Romero N, Robert P, Araya J, Lopez-Hernández J, Bozzo C, Navarrete E, Osorio A, Rios A (2006) Dietary fiber, amino acid, fatty acid and tocopherol contents of the edible seaweeds Ulva lactuca and Durvillaea antarctica. Food Chem 99:98-104

Özcan S, Șenyuva HZ (2006) Improved and simplified liquid chromatography/atmospheric pressure chemical ionization mass spectrometry method for the analysis of underivatized free amino acids in various foods. J Chromatogr A 1135:179-185

Ozdal T, Capanoglu E, Altay F (2013) A review on protein-phenolic interactions and associated changes. Food Res Int 51:954-970

Peña-Rodríguez A, Mawhinney TP, Ricque-Marie D, Cruz-Suárez LE (2011) Chemical composition of cultivated seaweed Ulva clathrata (Roth) C. Agardh. Food Chem 129:491-498 
Rodrigues D, Freitas AC, Pereira L, Rocha-Santos TAP, Vasconcelos MW, Roriz M, Rodríguez-Alcalá LM, Gomes AMP, Duarte AC (2015) Chemical composition of red, brown and green macroalgae from Buarcos bay in central west coast of Portugal. Food Chem 183: 197-207

Rupérez P (2002) Mineral content of edible marine seaweeds. Food Chem 79:23-26

Sabeena Farvin KH, Jacobsen C (2013) Phenolic compounds and antioxidant activities of selected species of seaweeds from Danish coast. Food Chem 138:1670-1681

Siró I, Kápolna E, Kápolna B, Lugasi A (2008) Functional food. product development, marketing and consumer acceptance-a review. Appetite 51:456-467

Stern JL, Hagerman AE, Steinberg PD, Mason PK (1996) Phlorotanninprotein interactions. J Chem Ecol 22:1877-1899

Suresh Kumar K, Ganesan K, Selvaraj K, Subba Rao PV (2014) Studies on the functional properties of protein concentrate of Kappaphycus alvarezii (Doty) Doty - an edible seaweed. Food Chem 153:353-360

The National Food Agency database, version 2017-12-15 (2018a) Herring raw. National Food Agency, Sweden. http://www7.slv.se/ SokNaringsinnehall/Home/FoodDetails/1241\#. Accessed 22 April 2018

The National Food Agency database, version 2017-12-15 (2018b) Salmon farmed Nowegian fjords raw. National Food Agency, Sweden. http://www 7.slv.se/SokNaringsinnehall/Home/ FoodDetails/1255\#. Accessed 22 April 2018

Undeland I, Kelleher SD, Hultin HO (2002) Recovery of functional proteins from herring (Clupea harengus) light muscle by an acid or alkaline solubilization process. J Ag Food Chem 50:7371-7379

Underwood AJ (1997) Experiments in ecology: their logical design and interpretation using analysis of variance. Cambridge University Press, Cambridge

United Nations, Department of Economic and Social Affairs, Population Division (2017) World population prospects: the 2017 revision, key findings and advance tables. Working Paper No. ESA/P/WP/248

USDA Food Composition Databases (2018a) Soy flour, full-fat, raw. United States Department of Agriculture, Agricultural Research Service. https://ndb.nal.usda.gov/ndb/foods/show $/ 303733$ ?n1=\% 7BQv\%3D1\%7D\&fgcd $=\& \operatorname{man}=\& 1$ facet $=\& \operatorname{count}=\& \max =$
$25 \&$ sort $=$ default $\&$ qlookup $=$ soy + flour $\&$ offset $=\&$ format $=$ Full \&new $=\&$ measureby $=\& Q v=1 \& d s=\& q \mathrm{t}=\& q p=\& q a=\& q n=\& q=$ \&ing. Accessed 22 April 2018

USDA Food Composition Databases (2018b) Egg, white, dried. United States Department of Agriculture, Agricultural Research Service. https://ndb.nal.usda.gov/ndb/foods/show/299433?n1=\%7BQv\% $3 \mathrm{D} 1 \% 7 \mathrm{D} \& \mathrm{fgcd}=\& \operatorname{man}=\& 1$ face $\mathrm{t}=\& \mathrm{count}=\& \max =25 \&$ sort $=$ default\&qlookup=egg + white $\&$ offset $=\&$ format $=$ Full \&new $=$ $\&$ measureby $=\& \mathrm{Qv}=1 \& \mathrm{ds}=\& \mathrm{qt}=\& \mathrm{qp}=\& \mathrm{qa}=\& \mathrm{q} \mathrm{n}=\& \mathrm{q}=\&$ ing . Accessed 22 April 2018

Vareltzis PK, Undeland I (2012) Protein isolation from blue mussels (Mytilus edulis) using an acid and alkaline solubilisation technique - process characteristics and functionality of the isolates. J Sci Food Ag 92:3055-3064

Veide Vilg J, Undeland I (2017) pH-driven solubilization and isoelectric precipitation of proteins from the brown seaweed Saccharina latissima - effects of osmotic shock, water volume and temperature. J Appl Phycol 29:585-593

Veide Vilg J, Nylund GM, Werner T, Qvirist L, Mayers JJ, Pavia H, Undeland I, Albers E (2015) Seasonal and spatial variation in biochemical composition of Saccharina latissima during a potential harvesting season for western Sweden. Bot Mar 58:435-447

Wahlström N, Harrysson H, Undeland I, Edlund U (2018) A strategy for the sequential recovery of biomacromolecules from red macroalgae Porphyra umbilicalis Kützing. Indust Engi Chem Res 57:42-53

WHO, Report of a joint WHO/FAO/UNU expert consultation (2002) Protein and amino acid requirements in human nutrition. WHO Technical Report Series 935

Wong KH, Cheung PCK (2000) Nutritional evaluation of some subtropical red and green seaweeds: Part I—proximate composition, amino acid profiles and some physico-chemical properties. Food Chem 71: 475-482

Wong KH, Cheung PCK (2001) Nutritional evaluation of some subtropical red and green seaweeds Part II. In vitro protein digestibility and amino acid profiles of protein concentrates. Food Chem 72:11-17

Yaich H, Garna H, Besbes S, Paquot M, Blecker C, Attia H (2011) Chemical composition and functional properties of Ulva lactuca seaweed collected in Tunisia. Food Chem 128:895-901

Yamaguchi S, Ninomiya K (2000) Umami and food palatability. J Nutr 130:921S-926S 